\title{
Black carbon aerosol reductions during COVID-19 confinement quantified by aircraft measurements over Europe
}

Ovid O. Krüger ${ }^{1}$, Bruna A. Holanda ${ }^{1}$, Sourangsu Chowdhury ${ }^{2}$, Andrea Pozzer $^{2}$, David Walter ${ }^{1}$, Christopher Pöhlker ${ }^{1}$, Maria Dolores Andrés Hernández ${ }^{3}$, John P. Burrows ${ }^{3}$, Christiane Voigt ${ }^{4,5}$, Jos Lelieveld ${ }^{2}$, Johannes Quaas ${ }^{6}$, Ulrich Pöschl ${ }^{1}$, and Mira L. Pöhlker ${ }^{1,6,7}$

${ }^{1}$ Multiphase Chemistry Department, Max Planck Institute for Chemistry, 55128 Mainz, Germany

2 Atmospheric Chemistry Department, Max Planck Institute for Chemistry, 55128 Mainz, Germany

${ }^{3}$ Institute of Environmental Physics, University of Bremen, 28359 Bremen, Germany

${ }^{4}$ Institute of Atmospheric Physics, Johannes Gutenberg University, 55128 Mainz, Germany

${ }^{5}$ Institute of Atmospheric Physics, German Aerospace Center (DLR), 82234 Oberpfaffenhofen, Germany

${ }^{6}$ Faculty of Physics and Earth Sciences, Leipzig Institute for Meteorology, University of Leipzig, 04103 Leipzig, Germany

${ }^{7}$ Experimental Aerosol and Cloud Microphysics Department, Leibniz Institute for Tropospheric Research, 04318 Leipzig, Germany

Correspondence: Mira L. Pöhlker (poehlker@tropos.de)

Abstract. The abrupt reduction in human activities during the first lockdown of the COVID-19 pandemic created unprecedented atmospheric conditions. To quantify the changes in lower tropospheric air pollution, we conducted the BLUESKY aircraft campaign and measured vertical profiles of black carbon (BC) aerosol particles over Western and

5 Southern Europe in May and June 2020. We compared the results to similar measurements of the EMeRGe EU campaign performed in July 2017 and found that the BC mass concentrations $\left(M_{\mathrm{BC}}\right)$ were reduced by about $47 \%$. For BC particle number concentrations, we found comparable reductions. Based on EMAC chemistry-transport model simulations, we find differences in meteorological conditions and flight patterns responsible for about $7 \%$ of the reductions in $M_{\mathrm{BC}}$, whereas $40 \%$ can be attributed to reduced anthropogenic emissions. Our results reflect the strong and immediate positive effect of changes in human activities on air quality and the atmospheric role of BC aerosols as a major air pollutant and climate forcing agent in the Anthropocene. 


\section{Introduction}

To subdue the exponential spread of the SARS-CoV-2 (severe acute respiratory syndrome coronavirus type 2), most European countries responded with substantial cuts in mobility and economic activities. This included forced and voluntary confinements such as travel bans, home-office and relinquished travel activities (Quaas et al., 2021a). Many of these behaviour modifications decreased fossil fuel combustion, a major source of atmospheric black carbon (BC) (e.g., Pöschl, 2005; Bond et al., 2013). This decrease is reflected in a roughly $30 \%$ decreased fossil fuel demand in early 2020 (Fig. A1). That reduction is attributed to $90 \%$ less air traffic in Europe (Schumann et al., 2021b) as well as strongly reduced road traffic (Figs. A2, A3, A4). These changes in anthropogenic emissions created unprecedented atmospheric conditions compared to the generally anthropogenic shaped continental aerosol burden (Andreae, 2007) and gave rise to the opportunity to measure airborne BC.

Several model studies use proxies like the strictness of the confinements or mobile phone data on transportation to show the impact of behavior changes on emissions (e.g., Forster et al., 2020; Le Quéré et al., 2020). Also satellite-based observations are used to track changes in trace gas concentrations, aerosol optical properties as well as cloud coverage (e.g., Quaas et al., 2021b; Schumann et al., 2021a; Li and Groß, 2021). A more accurate estimate on costs of spatial resolution is achieved with surface air pollution monitoring stations (e.g., Evangeliou et al., 2021; Petetin et al., 2020; Shi et al., 2021). All these studies have contributed to understanding the COVID-19 confinement's influence on the atmosphere and climate. Nevertheless, they fail to provide a precise quantification of air pollutants over a large spatial area with profiles of the lower tropospheric distribution. Here we present the first airborne in-situ observations of BC during the first COVID-19 lockdown in early 2020, showing a consistent data set for a large region along with the vertical distribution of $\mathrm{BC}$.

We measured refractory $\mathrm{BC}$ mass $\left(M_{\mathrm{BC}}\right)$ and particle number concentrations $\left(N_{\mathrm{BC}}\right)$ in the lower troposphere in Western and Southern Europe (Fig. 1). The measurements were carried out with a single particle soot photometer (SP2) mounted on the HALO (High Altitude and LOng range) research aircraft. This study compares data from in-situ measurements during nonconfinement conditions in July 2017 (during the EMeRGe EU campaign, Andrés Hernández et al., 2021) with those affected by reduced emissions in May and June 2020 (during the BLUESKY campaign, Voigt et al., 2021). Here we estimate to what extent the $\mathrm{BC}$ reductions are due to lower emissions and to other factors such as meteorological conditions and differences in flight tracks. Therefore we modeled $M_{\mathrm{BC}}$ along the flight tracks with the ECHAM/MESSy Atmospheric Chemistry (EMAC) model and used the differences in the model results to adjust our in-situ data for changes not related to reduced anthropogenic emissions. We show for the measurement period in 2020 a substantial reduction in BC compared to the measurements from 2017.

40 The fast response on the $\mathrm{BC}$ burden can be explained by its relatively short atmospheric residence time, ranging from some days to a few weeks (Holanda et al., 2020; Lund et al., 2018; Bond et al., 2013). Despite its short residence time, BC absorbs solar radiation which leads to strong positive radiative forcing (RF) (Ramanathan and Carmichael, 2008; Bond et al., 2013; Gustafsson and Ramanathan, 2016; Naik et al., 2021. In Press). Owing to its relatively short atmospheric residence time the 


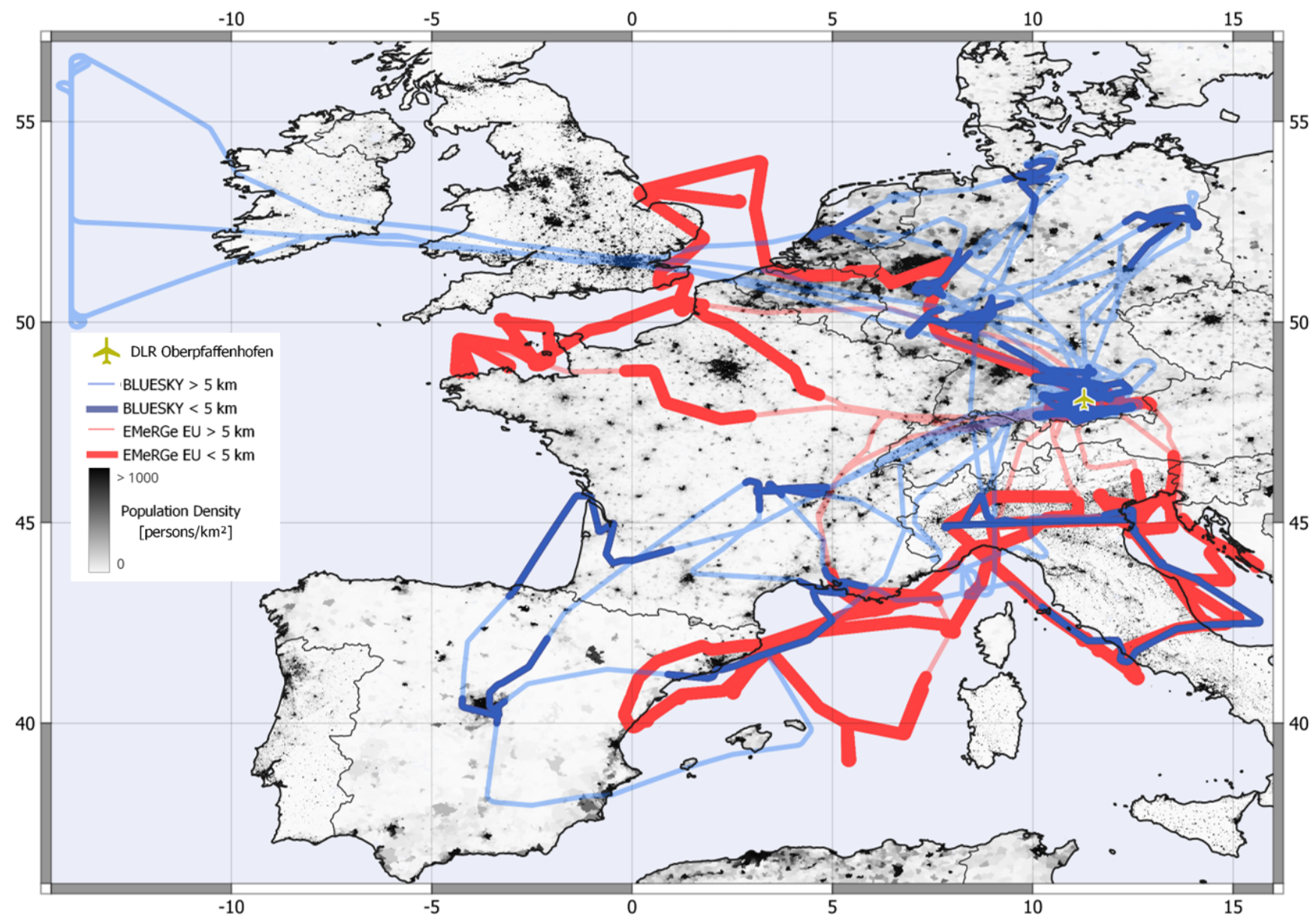

Figure 1. Flight tracks of the HALO EMeRGe EU (EM, in July 2017, Andrés Hernández et al., 2021) and BLUESKY (BS, in May and June 2020, Voigt et al., 2021) aircraft campaigns. Both campaings were conducted from the DLR airport in Oberpfaffenhofen in Southern Germany. Flight segments with altitudes below $5 \mathrm{~km}$, which yielded the measurement data for this study, are highlighted in the map. The population density is for the year 2020 (CIESIN, 2018).

$\mathrm{BC}$ burden response is nearly immediate to emissions changes. This immediacy makes BC an appropriate tracer for the rapid 


\section{Results}

The focal point of this study is the comparison between two HALO measurement campaigns, conducted over South and West Europe in 2017 and 2020 (Fig. 1 and A1). By using EMAC model simulations we quantify to what extent the pandemic-related confinements in 2020, on one hand, and other factors such as meteorology, on the other hand, influenced the observed $M_{\mathrm{BC}}$ reduction. In addition, the atmospheric distribution of $\mathrm{BC}$ and its dependency on the magnitude of emissions is analyzed. Furthermore, we examine the regional direct radiative effect of the $\mathrm{BC}$ reduction.

Determining the adjusted vertical distribution of the 2020 measurements (Fig. 2 D) enables us to quantify the emission reductions between both campaigns. Consequently, we calculated the difference between the two vertical distributions of $M_{\mathrm{BC}}$, retrieved from the EMAC model (Fig. $2 \mathrm{~A}$ and B). In the following we added this difference to the 2020 measurements (section A6), to generate an adjusted vertically integrated $M_{\mathrm{BC}}$ burden (section A8) of $159 \mathrm{mg} \mathrm{m}^{-2}$, whereas the actual measured burden is $143 \mathrm{mg} \mathrm{m}^{-2}$ and $261 \mathrm{mg} \mathrm{m}^{-2}$ for 2017 . Accordingly, a reduction of $101.8 \mathrm{mg} \mathrm{m}^{-2}$ is attributable to reduced anthropogenic emissions. This value corresponds to a $40 \%$ reduction in $M_{\mathrm{BC}}$ burden.

Beside an emission reduction, also other factors influence the differences in measured $M_{\mathrm{BC}}$. Figure 2 shows the median vertical distribution of measured and modeled $M_{\mathrm{BC}}$. For the model runs we used identical BC emission inventories (Hoesly et al., 2018). While the 2017 measurements are $15 \%$ underestimated by the model (Fig. 2 A), the measurements under confinement conditions are overestimated by $50 \%$ in the model, when considering 2017 emissions (Fig. 2 B). These results demonstrate that meteorological influences, different flight patterns and differences in seasonal emissions cannot explain the observed change in lower tropospheric $M_{\mathrm{BC}}$. As metric for the direct comparison of the two measurement campaigns, we use the model results to adjust our measurements. Therefore, we calculate the difference of the model results for 2017 and 2020 for each altitude bin. Overall, the difference in modeled $M_{\mathrm{BC}}$ between 2020 and 2017 accounts for a reduction of $7 \%$ relative to 2017. This difference is a consequence of different flight pattern, meteorological conditions and seasonal variations in emissions.

We find a good agreement for the the shape of the vertical $\mathrm{BC}$ distribution for measured and modelled $M_{\mathrm{BC}}$ profiles. Even though the concentrations in 2020 are strongly overestimated the vertical extent is well described by the EMAC simulations (see also $2 \mathrm{C}$ with reduced anthropogenic emissions). The Pearson coefficient of determination $\left(\mathrm{R}^{2}\right)$ for the vertical profiles of the observation-model comparison is 0.84 for EM and 0.89 for BS (Fig. A9). Based on the good agreement for the general vertical distribution during both campaigns, we conclude, that the shape of the vertical distribution of anthropogenic $\mathrm{BC}$ in the lower troposphere remains unaffected by the emission changes in 2020.

We compare the median vertical profiles in this study to simplify the heterogeneously distributed $M_{\mathrm{BC}}$ over Europe (Fig. 3). The vertical distribution of BC is strongly influenced by the planetary boundary layer (PBL) height, whereas its geographic pattern is more sensitive to emission hot spots like large cities or industrial areas. During both campaigns, $M_{\mathrm{BC}}$ in Southern Europe exceeds values in Western Europe (at latitudes north of $47^{\circ} \mathrm{N}$ ). During the measurements in 2017, we also encountered mixed biomass burning and anthropogenic pollution in and above the PBL. The biomass burning influence was prominent 
in Southern Europe from $40^{\circ} \mathrm{N}$ and $42^{\circ} \mathrm{N}$ latitude (Fig. $3 \mathrm{~A}$ ). The defined BC plume between 2000 and $3500 \mathrm{~m}$ altitude in Southern Europe is dominated by biomass burning emissions. An analogy can be drawn to previous studies, which reported a similar pronounced stratification of biomass burning smoke above the PBL (Holanda et al., 2020). To be less sensitive to event-like measurements, we use median values for the comparison of the two aircraft campaigns (see also section A5).

The measured values for $M_{\mathrm{BC}}$ in 2020 are $47 \%$ lower, when disregarding the model-based adjustment described above. For the refractory $\mathrm{BC}$ particle $(\mathrm{rBC})$ number concentration $\left(N_{\mathrm{BC}}\right)$, we find $48 \%$ lower concentrations (Fig. $\left.2 \mathrm{E}\right)$. The good agreement between $M_{\mathrm{BC}}$ and $N_{\mathrm{BC}}$, is in accordance with the comparable median size distribution of the $\mathrm{rBC}$ particles between the two measurement campaigns, with $\mathrm{rBC}$ core diameters $\left(\mathrm{D}_{\mathrm{rBC}}\right)$ ranging between $\sim 120$ to $180 \mathrm{~nm}$ (Fig. A6). The range for $\mathrm{D}_{\mathrm{rBC}}$ agrees with literature values for urban emissions (e.g. Schwarz et al., 2008; Liu et al., 2014).

To estimate the effect the reductions have on Earth's radiative budget, we calculated the regional aerosol direct radiative effect in the measurement area. Therefore we reduced anthropogenic BC emissions in our EMAC simulation by $40 \%$ and found a cooling effect of $0.06 \mathrm{~W} \mathrm{~m}^{-2}$ (Fig. A8) at the top of the atmosphere (TOA). This reduction due to a reduction of anthropogenic BC emissions by $40 \%$ is as large as the global-mean BC radiative forcing, as assessed by the IPCC AR6 (Naik et al., 2021. In Press).

\section{Discussion}

We present the first measurement study showing the influence of the unprecedented reduction in atmospheric pollution in 2020 on BC vertical distribution. Our measurements cover a large spatial area, measured on a rather short time scale. Thus, we deliver a representative data set, showing the changes in atmospheric $\mathrm{BC}$ concentration. We benefit in this comparison from the large spatial coverage, measured with the same instrumentation. In addition, the vertical extent of pollutants emitted in the PBL is observed with a high accuracy. In the discussion section we compare our aircraft data with recent studies, quantifying the impact of the COVID-19 confinements with other metrics. We find a general agreement, even though most studies use 2019 or a multiyear average as reference for the comparison, while we compare two rather short periods in 2017 and 2020. We also investigate potential reasons for the reduction of atmospheric $\mathrm{BC}$ and other pollutants and consequently analyze data published by EUROSTAT on fossil and solid fuel demand.

The $40 \%$ reduced $M_{\mathrm{BC}}$ we find, exceeds the mean value for Europe (11\%) reported by Evangeliou et al. (2021). Nevertheless, our results fall within the reported range from $42 \%$ to $8 \%$ for Southern and Western Europe. Also studies with stronger regional focus agree well with our results. Moreda-Piñeiro et al. (2021) found for the Southwest Atlantic region of Spain, BC reductions between 29 to $51 \%$. Beside BC, also other atmospheric constituents were found to be reduced during the 2020 confinements. For the Po Valley, Lonati and Riva (2021) found benzene reduced by roughly $40 \%$ in May 2020. Benzene is a volatile organic compound (VOC) primarily emitted by road traffic and in good correlation with anthropogenic BC emissions (Wren et al., 

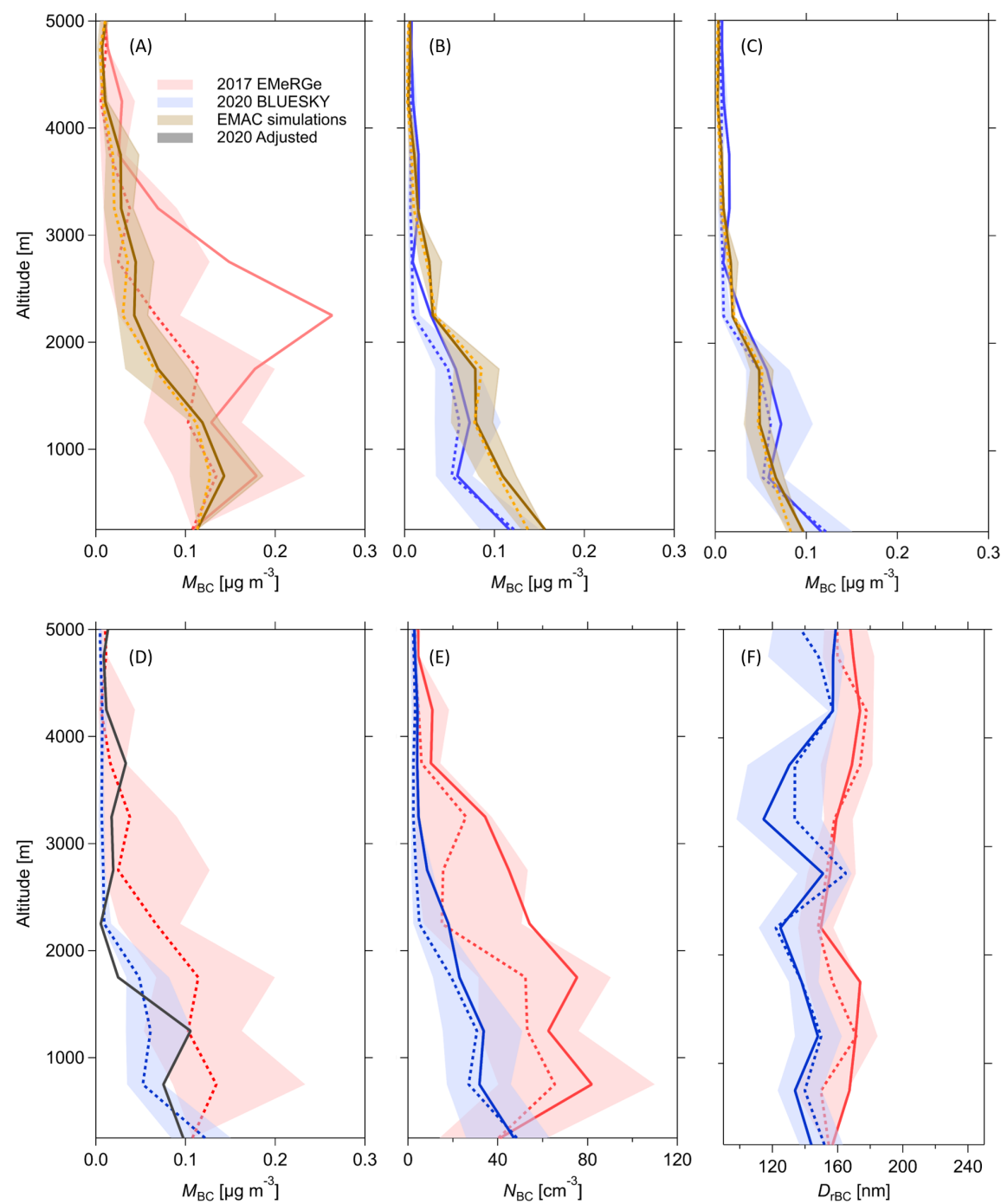

Figure 2. Vertical distributions of measured and modeled $M_{\mathrm{BC}}(\mathrm{A}, \mathrm{B}, \mathrm{C}$, and F). Solid lines represent average values, dashed lines represent median values shading marks the interquartile range. (A) shows EM 2017 measurements and EMAC simulations with initial 2014 emission inventories. (B) shows BS 2020 measurements and EMAC simulations with initial 2014 emission inventories. (C) shows BS measurements and EMAC simulations with anthropogenic BC emission reduced by $40 \%$ to match the HALO 2020 observations. (D) shows EM and BS measurements for comparison between the two campaigns, the data is the same as also shown in panels (A) and (B). The grey solid line shows the weather and seasonal adjusted median $M_{\mathrm{BC}}$ concentration expected for BS measurements in 2020 (section A6). The adjusted value is based on non-confinement influences retrieved from the difference of the EMAC simulations for BS and EM. It represents the expected measurement value, assuming the same meteorological and seasonal conditions for both campaigns. The difference between the medians of EM and adjusted BS represents the emission reduction. (E) shows the measured $M_{\mathrm{BC}}$ for EM in 2017 and BS in 2020. (F) shows the geometric mean refractory BC core diameters $\left(D_{\mathrm{rBC}}\right)$ for EM in 2017 and BS in 2020. 

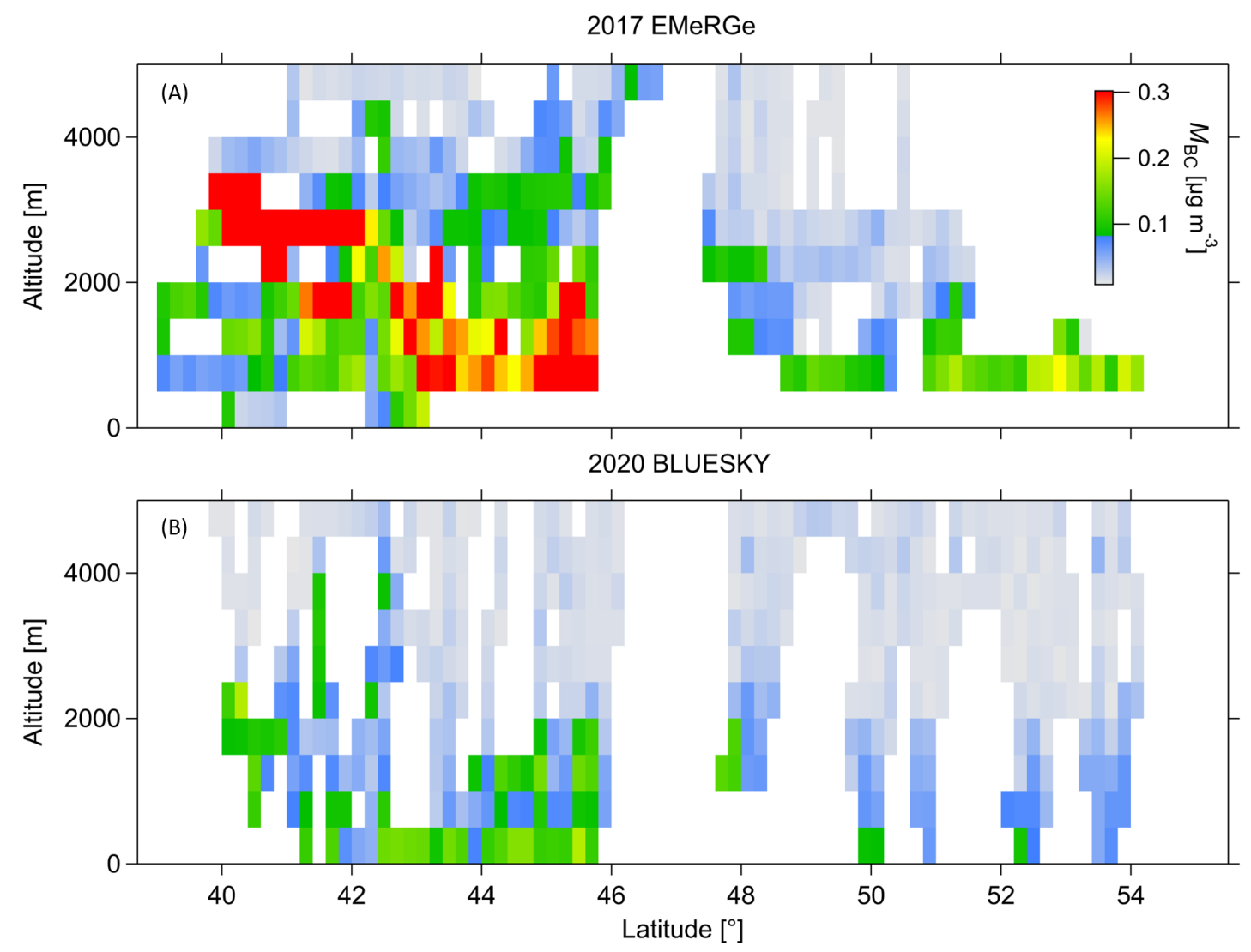

Figure 3. (A) Cross section of $M_{\mathrm{BC}}$ for 2017 EMeRGe EU measurements. Averages for all data falling into a grid point of $0.2^{\circ}$ latitude and $500 \mathrm{~m}$ altitude. The color scale ranges from 0 to $0.3 \mu \mathrm{g} / \mathrm{m}^{3}$. Averages exceeding this range are shown in red. (B) as (A) but for the 2020 BLUESKY measurements.

2018). Petetin et al. (2020) found $\mathrm{NO}_{2}$, as another traffic-related pollutant, decreased between 41 and $55 \%$ in Spain. By combining satellite and surface in-situ measurements with numeric modeling, Venter et al. (2020) found fine particulate matter (PM2.5) reduced by $31 \%$. Apart from measurements, also proxy data are used to quantify the effect of the confinements on the atmosphere. Forster et al. (2020) shows globally a decrease in BC of up to $22 \%$ for the lockdown period and around $15 \%$ in May 2020. When only considering the countries probed in our measurement flights, the reduction is $40 \%$ in May and $20 \%$ in June 2020. These literature values, based on mobility data from Google and Apple, agree well with our measurements. All of the above-mentioned studies, analyzing the reductions in traffic related pollutants and proxies, are in a similar range as our results.

Less traffic is identified as the driving force for improved air quality in 2020 (Le Quéré et al., 2020). This is reinforced by the drop in fossil fuel demand during the confinements in 2020 (Figs. A1, A2, A3, A4). For May 2020, fossil fuel demand was 
$30 \%$ below the 2017 level (Fig. A1). We found the largest reduction in kerosene demand with $75 \%$ (Fig. A4). For road traffic fuels, the decrease is roughly $20 \%$ (Diesel $-18 \%$, Fig. A2 and motor spirits $-32 \%$, Fig. A3). Other than motor spirits, Diesel is widely used in the transportation sector and thus the impact of the confinements in 2020 is relatively smaller. The higher decrease in motor spirits and kerosene can be attributed to the drop in passenger traffic, due to travel bans, home-office, and relinquished traveling activities.

Beside reduced emissions due to the COVID-19 confinements, other emission reductions took place between the two measurement campaigns. The total consumption of solid fuels in 2020 was around $42 \%$ below the corresponding value for 2017 (A5). However, solid fossil fuel, only accounts for a small fraction (3\%) of the BC emissions from power generation (McDuffie et al., 2020). Accordingly, reductions in solid fossil fuel combustion for power generation have only little influence $(<1 \%)$ on the absolute $M_{\mathrm{BC}}$ burden. Due to higher emission standards there are multi-year declines of the $\mathrm{BC}$ burden reported for the Northern Hemisphere (e.e., Singh et al., 2018; Querol et al., 2013; Kutzner et al., 2018). Based on surface measurement stations Kutzner et al. (2018) found an annual reduction between 1 and $3 \%$ for German urban background and rural sites in the period between 2005 until 2014. At traffic sites the annual reduction was as high as $5 \%$. For a kerbside station in London, Singh et al. (2018) found up to $8 \%$ annual reduction in BC, whereas the reduction at rural and remote sites was as little as 0.6\%. Querol et al. (2013) obtains similar results for Spain with a high BC reduction in urban areas and little to statistically insignificant reductions in rural regions. The $\mathrm{BC}$ concentrations in our study falls within the range reported by Querol et al. (2013) for remote and rural sites in Spain. It has to be noted that BC concentrations show both a strong vertical gradient and a geographic pattern, highly sensitive to emission hot spots like traffic sites, domestic combustion sources or industrial areas. Thus the median vertical profiles shall be understood as lower tropospheric background concentrations with an anticipated annual reduction in the range of rural and urban background concentrations. Hence, around 3 to $9 \%$ of the reduction we found should be attributed to general emission reductions.

The local top of the atmosphere direct radiative effect of $\mathrm{BC}$ over continental Europe is considerably small, due to the low surface albedo and relatively low BC concentrations (Heald et al., 2014). Due to BC's ability to absorb solar radiation the reduced emissions show a net warming effect in the lower troposphere, by increasing the incoming radiation. However, there is a change of sign at pressure levels below $700(\backsim 3000 \mathrm{~m})$ resulting in an overall cooling effect at the top of the atmosphere. Nevertheless, to get a full picture of the atmospheric response to the unprecedented atmospheric situation during the COVID-19 pandemic, more sophisticated studies are needed at this point. In particular the long-range transport of anthropogenic pollutants to remote regions like higher latitudes, where its climate impact is amplified by a high surface albedo and an increased ice melting due to deposition of atmospheric $\mathrm{BC}$ on snow and ice. Also, research on the long- and short-term radiative effects in combination with other relevant species will be very valuable for atmospheric science and policy makers. For these studies we present a good estimate for the near immediate response of $M_{\mathrm{BC}}$ in the area of Southern and Western Europe. Furthermore, we show that proxy data as used by Forster et al. (2020) or EUROSTAT data can serve well for the improvement and the definition of emission inventories during the exceptional atmospheric circumstances during the pandemic. 


\section{Conclusions}

We showed that lower tropospheric median $M_{\mathrm{BC}}$ was decreased by $40 \%$ in Southern and Western Europe in 2020 compared to 2017. This reduction is attributed to two main reasons, the general decreasing trends of BC emissions in Germany and Europe accounting for 3 to $9 \%$ and the confinement of human movement as a result the measures taken to minimize the spread of COVID-19 accounting for 31 to $37 \%$. The effect of COVID-19 confinements on the atmospheric $M_{\mathrm{BC}}$ found in this study generally agrees with earlier studies using ground based and proxy data to estimate the confinement's effect. In addition to earlier studies, we present the first measurement results of airborne BC in 2020. We provide a consistent data set for a large spatial area and the vertical extent of $M_{\mathrm{BC}}$ and $N_{\mathrm{BC}}$.

Our results confirm the near immediate atmospheric response of $M_{\mathrm{BC}}$ and $N_{\mathrm{BC}}$ to anthropogenic activities. Reduced mobility drives the $\mathrm{BC}$ reductions in the lower troposphere. Some of these changes in mobility, such as reduced road and air traffic due to home-office and video conferences, should be sustained into working culture. Model studies using our results can quantify the positive effects on public health and the atmosphere due to reductions in air pollution. Our study extends current knowledge about the distribution of pollutants in the atmosphere. It demonstrates that the impact of measures, which improve air quality, also influence climate. It thereby contributes to one of the most important challenges of this century, namely how to mitigate climate change.

Data availability. The data set for the vertical distribution of $M_{\mathrm{BC}}$ (Table A1), $N_{\mathrm{BC}}$ (Table A2), the rBC core size distribution (Table A3) and the vertically integrated $M_{\mathrm{BC}}$ burden (Table A4) are provided in the supplementary material. The original data set is available in NASA Ames format under https://doi.org/10.xxxxx/x. Further data from the two HALO missions is available at the HALO database (https://halo-db. pa.op.dlr.de/). For data requests beyond the available data, please refer to the corresponding author. 


\section{Appendix A: Materials and Methods}

We investigate the impact of the first COVID-19 lockdown in Europe on atmospheric BC concentrations with aircraft measurements from 2017 and 2020. For a better understanding of impact-factors on BC other than emission reductions we model results of $M_{\mathrm{BC}}$ along the flight tracks. We used the resulting reductions to calculate the radiative influence due to lower $\mathrm{BC}$ emissions.

\section{A1 Studied area}

The measurement flights were carried out in Southern and Western European airspace (Fig. 1). The countries we focus on in this study are Germany, France, Spain, Italy, Netherlands, Belgium and Luxembourg. These countries are also used for the comparison of our results to other data sets and publications.

From 10 until 28 July 2017 the Effect of Megacities on the transport and transformation of pollutants on the Regional and Global scales (EMeRGe EU) was investigated in Europe (Andrés Hernández et al., 2021). The focus of EMeRGe EU determined the flight tracks, to be in the lower troposphere, where anthropogenic pollution is most abundant. The flights were performed predominantly up- and down-wind of dense populated regions.

We compare the results of EMeRGe EU to BLUESKY including the CAFE EU project (Chemistry of the Atmosphere: Field Experiment in Europe), from 23 May until 09 June 2020 (Voigt et al., 2021). The central point during BLUESKY was to investigate the effects of the COVID-19 confinements on the atmosphere. This included measurements of urban pollution in the lower troposphere, but also effects of reduced air traffic. Therefore, some measurements were performed in passenger aircraft cruising altitudes in the upper troposphere and lowermost stratosphere (Schlager et al. 2021 in prep.).

The short lifetime of $\mathrm{BC}$ hinders it from getting well mixed in the free troposphere and leads to a strong vertical gradient in its concentration. An accumulation of $\mathrm{BC}$ can be found in the lower troposphere and especially in the planetary boundary layer (PBL). On top of the PBL there is some turbulent and convective mixing taking place, introducing PBL pollutants, like BC, into the lower troposphere (Andreae et al., 2018; Schwarz et al., 2017). Moreover BC concentrations in the middle and upper troposphere are rather driven by wildfires and long range transport (Holanda et al., 2020; Ditas et al., 2018) than by anthropogenic pollution. These properties of atmospheric BC led us to focus on the lower troposphere, up to $5000 \mathrm{~m}$.

\section{A2 Temporal course of country response measures to COVID-19 compared to measurement period}

The regional severity of the COVID-19 outbreak and thus the response by the European states was not concerted. A dynamic and scattered change in restrictions was its outcome. Nevertheless, all countries covered by our measurements experienced a substantial cut in both, private mobility as well as mobility on companies business. In Figure A7 we show the governmental response index as indicator of the confinement strengths for selected countries. The data is downloaded form the Oxford Covid- 
19 Government Response Tracker (https://github.com/OxCGRT/covid-policy-tracker, last access 06.07.2021) and further described in Hale et al. (2021). Beside the patchy responses of particular states and provinces, the EU imposed a comprehensive travel ban for non-EU citizens, with a drop in air-traffic as outcome. This ban was in effect form 18 March 2020 until 30 June 2020 and thus covered the whole measurement period (https://data.consilium.europa.eu/doc/document/ST-9208-2020-INIT/ de/pdf).

The measurement period took place in the later lockdown period, when still many confinements were in effect and travel activities remained low.

\section{A3 Airborne BC measurements}

Both measurement campaigns were conducted with the High Altitude and LOng range (HALO) research aircraft (G550, Gulfstream, USA), a modified long-range business jet. HALO is based at the German Aerospace Center (DLR) in Oberpfaffenhofen, Germany. Near isokinetic aerosol sampling was achieved with the HALO Aerosol Submicrometer Inlet mounted on the fuselage outside of the aircraft boundary layer (Andreae et al., 2018).

The refractory black carbon (rBC) was measured with an eight-channel Single Particle Soot Photometer (SP2, Droplet Measurement Technologies, Longmont, USA). The SP2 quantifies rBC and non-absorbing particles using laser-induced incandescence and scatter signals (Stephens et al., 2003; Schwarz et al., 2006). Particles with a rBC core absorb the laser light and evaporate. The emitted incandescence signal is linearly proportional to the mass of the rBC cores (Laborde et al., 2013). The SP2 used for this study is sensitive to $\mathrm{rBC}$ cores in the size range between 70 to $500 \mathrm{~nm}$ mass-equivalent diameter, assuming a density of $1.8 \mathrm{~g} \mathrm{~cm}^{-3}$.

The SP2 incandescence signal was calibrated at the beginning, during, and at the end of each campaign with size-selected fullerene soot particles (Alfa Aesar Lot W08A039). The scattering signal was calibrated with spherical polystyrene latex size standards $(208,244$, and $288 \mathrm{~nm})$ and size selected ammonium sulfate particles using a differential mobility analyzer (Grimm Aerosol Technik, Ainring, Germany). The results of all calibrations for both campaigns agreed within their uncertainty ranges, confirming good instrument stability throughout the comparison. The uncertainty for SP2 measurements is $5 \%$ for $N_{\mathrm{BC}}$ and $10 \%$ for $M_{\mathrm{BC}}$ (Laborde et al., 2012). The measurement data was analysed with the Paul-Scherrer Institute (PSI) SP2 toolkit (Gysel-Beer and Corbin, 2019) and adjusted to standard temperature and pressure (STP, $T=273.15 \mathrm{~K}, p=1013.25 \mathrm{hPa}$ ). Throughout the analysis we use the BC data without a correction for the lower cutoff of the SP2. Due to the large contribution of anthropogenic $\mathrm{BC}$ emissions on our measurements and the high uncertainty in the size distribution for diameters below the SP2 detection limit we do not fit the size distribution to a log normal distribution. Furthermore for $M_{\mathrm{BC}}$, diameters below $100 \mathrm{~nm}$ do not play a significant role, regardless their potentially dominating role for $N_{\mathrm{BC}}$ and importance for the $\mathrm{BC}$ surface area (Seinfeld and Pandis, 2006; Pileci et al., 2021; Schwarz et al., 2008; Reddington et al., 2013). 


\section{A4 ECHAM/MESSy model}

We used the ECHAM/MESSy Atmopheric Chemistry (EMAC) model at T63 horizontal spectral resolution (approx. $1.88^{\circ} \times$ $1.88^{\circ}$ ) and with 31 hybrid terrain following pressure levels up to10 $\mathrm{hPa}$ in the lower stratosphere (Jöckel et al., 2005, 2010; Pozzer et al., 2012; Lelieveld et al., 2019). The core atmospheric model employed here is the $5^{\text {th }}$ generation European Centre Hamburg (ECHAM5) general circulation model. EMAC includes multiple sub-models that represent the tropospheric and stratospheric processes and their interaction with the biosphere. We used the Modular Earth Submodel System (MESSy, v.2.54, Jöckel et al., 2010; Beer et al., 2020) to link submodels that describe emission, aerosols, atmospheric chemistry, deposition and other processes. The GMXe (Global Modal Aerosol Extension) submodel (Pringle et al., 2010) was employed to simulate the microphysical processes in aerosols and the gas/aerosol portioning. The GMXe organizes the aerosols into hydrophilic and hydrophobic modes. The hydrophilic mode encompasses aerosols in the entire size spectrum (coarse, accumulation, Aitken and nucleation), whereas the hydrophobic mode does not consider the nucleation mode. We updated the assumption in the GMXe by emitting black and organic carbon in accumulation and Aitken modes following a recent study (Paasonen et al., 2016). The gas phase and heterogeneous chemistry was simulated with the MECCA submodel (Sander et al., 2005, 2019). The ORACLE (Organic Aerosol Composition and Evolution) submodel (Tsimpidi et al., 2014, 2018) was used to simulate the atmospheric evolution and composition of the organic aerosols. The aerosol optical properties are calculated by the AEROPT (AERosol OPTical properties) submodel (Lauer et al., 2007; Pozzer et al., 2012; Dietmüller et al., 2016; Klingmüller et al., 2019), which assumes the aerosol components in each mode to be spherical, well mixed and with volume averaged refractive indices. The radiation calculations were done with the RAD submodel (Dietmüller et al., 2016) which is equipped with logical switches for diagnostically calling the radiation schemes multiple times within one model setup for calculation radiative forcings. The S4D (Sampling in 4 Dimensions) submodel (Jöckel et al., 2010) was used to interpolate and write the model outputs, online at spatial and temporal steps of the EMeRGe EU and BLUESKY aircraft measurements. Apart from these submodels, the following MESSy submodels were enabled, AIRSEA, BIOBURN, CLOUD, CLOUDOPT, CONVEC, CVTRANS, DDEP, E5VDIFF, H2O, JVAL, LNOX, OFFEMIS, ONEMIS, ORBIT, SCAV, SEDI, SORBIT, SURFACE, TNUDGE and TROPOP. Explicit description of each of these submodels can be found in the MESSy submodel list (https://www.messy-interface.org/ current/auto/messy_submodels.html).

The EMAC global simulations, nudged towards the ERA-5 meteorological re-analyses were performed for two time periods January to July 2017 and January to June 2020 to coincide with the EMeRGe EU and BLUESKY aircraft campaigns respectively. Over the past decade, EMAC model simulations of aerosols and trace gases have been extensively assessed against ground measurements and satellite retrievals (Lelieveld et al., 2007; Kerkweg et al., 2006; Lelieveld et al., 2019; Tsimpidi et al., 2018; Brühl et al., 2015; Pozzer et al., 2015; Zimmermann et al., 2020). Here, we use the monthly varying Community Emissions Data System (CEDS) anthropogenic emission inventory of 2014 , Hoesly et al. (2018) at $0.5^{\circ} \times 0.5^{\circ}$ resolution for the primary emitted species including $\mathrm{CO}$ (carbon monoxide), $\mathrm{NO}_{2}$ (oxides of nitrogen), $\mathrm{SO}_{2}$ (sulfur dioxide), $\mathrm{NH}_{3}$ (ammonia), $\mathrm{BC}, \mathrm{OC}$ (organic carbon) and NMVOCs (non methane volatile organic compounds). Biomass burning emissions were obtained from the Global Fire Assimilation System (GFAS) inventory Kaiser et al. (2012). The emissions data were then pre-processed 
and vertically distributed in six emission heights following Pozzer et al. (2012). Residential and commercial fuel use was the largest emitter of BC (46934 t per year) over the region investigated in this study (Fig. 1, e.g. latitude between -5 and $16^{\circ}$ and longitude between 37.5 and $54.5^{\circ}$ ), followed by emissions from land transportation ( $36023 \mathrm{t}$ per year), power generation (22161 t per year), industrial combustion and process (17737 t per year), agricultural waste burning (1283 t per year) and air traffic (0.4067 t per year). For comparisons with the EMeRGe EU and BLUESKY aircraft measurements, BC concentration was diagnosed along the aircraft routes. A sensitivity model simulation was performed by reducing anthropogenic $\mathrm{BC}$ emissions from all sectors by $40 \%$ to compare with the BLUESKY observations.

\section{A5 EMAC model evaluation}

Beside the comparison between the EMAC results for $M_{\mathrm{BC}}$ (Fig. A9), we also compare the modeled and observed ambient temperature as an independent variable (Fig. A10). The $\mathrm{R}^{2}$ for the ambient temperature observation-model comparison is close to unity, indicating a successful nudging of synoptic variables and that the meteorological conditions during the relevant time period are simulated adequately. Peaks in $M_{\mathrm{BC}}$ due to biomass burning emissions during EMeRGe EU (Fig. A9) are underestimated by the model. However, the median for the $500 \mathrm{~m}$ bins turns out to be robust against these outliers $\left(\mathrm{R}^{2}\right.$ of 0.84 with a median absolute deviation (MAD) of $0.13 \mu \mathrm{g} / \mathrm{m}^{3}$ for $\mathrm{EM}$ and $\mathrm{R}^{2}=0.88, \mathrm{MAD}=0.06 \mu \mathrm{g} / \mathrm{m}^{3}$ for BS). Whereas the average for the vertical profiles are more sensitive to peak concentrations, leading to a significantly smaller $\mathrm{R}^{2}=0.24$ with a high standard deviation (STD) of $0.77 \mu \mathrm{g} / \mathrm{m}^{3}$ for EMeRGe EU. For BLUESKY the $\mathrm{R}^{2}=0.93$ with $\mathrm{STD}=0.1 \mu \mathrm{g} / \mathrm{m}^{3}$ is slightly higher, compared to median values.

\section{A6 Accounting for different flight pattern and seasonal and meteorological variability}

The major difficulty in comparing atmospheric aerosol measurements is the strong meteorological, regional and seasonal influence on the distribution and concentration of aerosol. This is due to (I) removal processes driven by the hydrological circle, dominated by cloud processing (Ohata et al., 2016). (II) The extent of the PBL, determining the concentration and vertical extent of bulk BC and other aerosol species (S. Raj et al., 2021). (III) Seasonal variations in emission types and strengths. Beside these factors, influencing the actual BC burden, also the flight tracks have an important influence on the measurement results.

We therefore used EMAC model simulations of $M_{\mathrm{BC}}$ along the flight tracks with different emission scenarios (details in section A4). First, we run the model for 2017 and 2020 with unmodified 2017 emission inventories (Hoesly et al., 2018). For the comparison we use one minute average measurement data $30 \mathrm{~s}$ prior and $30 \mathrm{~s}$ after each model output. In the next step we calculate the descriptive statistics for vertical bins of $500 \mathrm{~m}$. The difference for each altitude bin between the results of the EMAC runs for 2017 and 2020 is added to the 2020 measurement results to account for differences unrelated to emission changes (e.g., flight pattern, meteorology, and differences in emissions pattern as well as emissions from wildfires). The adjusted vertical 
profile for the 2020 measurements is then compared to the 2017 measurements to quantify the emission reductions according

$B C_{\mathrm{red}}=\frac{M_{\mathrm{BC} 2017 \mathrm{H}}-\left(M_{\mathrm{BC} 2020 \mathrm{H}}+\left(M_{\mathrm{BC} 2017 \mathrm{M}}-M_{\mathrm{BC} 2020 \mathrm{M}}\right)\right)}{M_{\mathrm{BC} 2017 \mathrm{H}}}$

Where $B C_{\text {red }}$ is the unit-less reduction factor in $M_{\mathrm{BC}}$ attributed to the COVID-19 confinements, $M_{\mathrm{BC} 2017 \mathrm{H}}$ and $M_{\mathrm{BC} 2020 \mathrm{H}}$ stands for HALO measurements. While the difference between the EMAC results $\left(M_{\mathrm{BC} 2017 \mathrm{M}}\right.$ and $\left.M_{\mathrm{BC} 2020 \mathrm{M}}\right)$ is the adjustment factor, introduced earlier.

\section{A7 Vertical and latitudinal distribution of $M_{\mathrm{BC}}$ and $N_{\mathrm{BC}}$}

The vertical profiles of $M_{\mathrm{BC}}$ (Fig. 2) and the microphysical BC properties in Figures2 D and A6 represent the data $30 \mathrm{~s}$ prior and $30 \mathrm{~s}$ after each model output during the two campaigns. The $N_{\mathrm{BC}}$ vertical profile (Fig. $2 \mathrm{E}$ ) contains the whole measurement data, since no EMAC simulations for $N_{\mathrm{BC}}$ were conducted. To obtain the vertical profiles the measurement and model data are concatenated in $500 \mathrm{~m}$ altitude bins. The statistical values given in the particular figure and table are calculated for each bin with IGOR Pro (WaveMetrics Inc. version 7.08).

Also the log normal size distributions, given in Figures2 D and A6, are calculated for the concatenated data in each altitude bin. We used the following function according to (Heintzenberg, 1994),

$f(x)=\frac{A}{\sqrt{2 \pi} \log (\sigma)} \exp \left[-\frac{\left(\log (x)-\log \left(D_{\mathrm{g}}\right)\right)^{2}}{2 \log ^{2}(\sigma)}\right]$

with $A$ as a free parameter, $D_{\mathrm{g}}$ as mean geometric diameters and the widths (i.e., the standard deviations, $\sigma_{\mathrm{g}}$ ) of the core size distributions.

\section{A8 Vertically integrated $M_{\mathrm{BC}}$ burden}

The vertically integrated $M_{\mathrm{BC}}$ burden per surface area is calculated as the integral of the median vertical $M_{\mathrm{BC}}$ concentration. Note that the $M_{\mathrm{BC}}$ per cubic metre in the vertical profiles is STP corrected. Thus, we scaled the altitude bins with a scaling factor $\left(S_{\mathrm{P}}\right.$, Table A4) based on the pressure altitude. Equation A3 shows the calculation of $\left(S_{\mathrm{P}}\right)$ with $h_{\text {bin }}$ as the altitude of the corresponding altitude bin in the vertical profile. 
$S_{\mathrm{P}}=\frac{1}{\left(1-\frac{h_{\text {bin }}}{4307.69396 \mathrm{~m}}\right)^{5.2553026}}$

\section{A9 Radiative impact of the changed $M_{\mathrm{BC}}$}

The radiative effect due to $40 \%$ reduction in $M_{\mathrm{BC}}$ is calculated with EMAC for the local radiative forcing (latitude between -5 and $16^{\circ}$ and longitude between 37.5 and $54.5^{\circ}$ ) for the months May and June. The radiative effect is the difference between one run with full aerosol emissions and one with a $40 \%$ reduced anthropogenic $M_{\mathrm{BC}}$ emissions. The calculations are done for short wave radiation with clear sky conditions.

\section{A10 EUROSTAT data for fossil and solid fuels}

Data published by EUROSTAT is used to investigate the reductions in fossil fuel demand during the confinement period in 2020 (https://ec.europa.eu/eurostat/databrowser/view/NRG_JODI_custom_482779/default/table last access 25.01.2021). Furthermore, the difference in solid fossil fuel demand between 2017 and 2020 is used to analyze important drivers for the BC reduction, other than the COVID-19 confinements in 2020 (https://ec.europa.eu/eurostat/databrowser/view/NRG_ CB_SFF_custom_1131819/default/table?lang=en last access 08.07.2021 and https://ec.europa.eu/eurostat/databrowser/view/ NRG_CB_SFFM_custom_1558586/default/table?lang=en last access 12.11.2021). 
https://doi.org/10.5194/acp-2021-1100

Preprint. Discussion started: 7 January 2022

(c) Author(s) 2022. CC BY 4.0 License.

Table A1. Average and median $M_{\mathrm{BC}}$ from HALO observations and EMAC simulations. Values in column altitude represent centre of corresponding $500 \mathrm{~m}$ altitude bin.

\begin{tabular}{llllllllllll}
\hline \multicolumn{4}{c}{ EMeRGe EU } & \multicolumn{9}{c}{ BLUESKY } \\
\multicolumn{4}{c}{} & \multicolumn{3}{c}{ Observations } & \multicolumn{2}{c}{ EMAC } & \multicolumn{2}{c}{ Observations } & \multicolumn{2}{c}{ EMAC } & \multicolumn{2}{c}{ EMAC 40\% reduced } \\
Altitude & Avg & Median & Avg & Median & Avg & Median & Avg & Median & Avg & Median \\
{$[\mathrm{m}]$} & {$\left[\mu \mathrm{g} / \mathrm{m}^{3}\right]$} & {$\left[\mu \mathrm{g} / \mathrm{m}^{3}\right]$} & {$\left[\mu \mathrm{g} / \mathrm{m}^{3}\right]$} & {$\left[\mu \mathrm{g} / \mathrm{m}^{3}\right]$} & {$\left[\mu \mathrm{g} / \mathrm{m}^{3}\right]$} & {$\left[\mu \mathrm{g} / \mathrm{m}^{3}\right]$} & {$\left[\mu \mathrm{g} / \mathrm{m}^{3}\right]$} & {$\left[\mu \mathrm{g} / \mathrm{m}^{3}\right]$} & {$\left[\mu \mathrm{g} / \mathrm{m}^{3}\right]$} & {$\left[\mu \mathrm{g} / \mathrm{m}^{3}\right]$} \\
250 & 0.108 & 0.108 & 0.113 & 0.113 & 0.117 & 0.122 & 0.156 & 0.137 & 0.110 & 0.097 \\
750 & 0.179 & 0.134 & 0.143 & 0.128 & 0.059 & 0.052 & 0.109 & 0.105 & 0.077 & 0.073 \\
1250 & 0.129 & 0.103 & 0.119 & 0.112 & 0.072 & 0.061 & 0.079 & 0.078 & 0.056 & 0.055 \\
1750 & 0.177 & 0.114 & 0.069 & 0.065 & 0.057 & 0.048 & 0.079 & 0.086 & 0.055 & 0.060 \\
2250 & 0.263 & 0.067 & 0.043 & 0.030 & 0.029 & 0.009 & 0.031 & 0.034 & 0.022 & 0.024 \\
2750 & 0.149 & 0.025 & 0.044 & 0.036 & 0.009 & 0.008 & 0.027 & 0.025 & 0.019 & 0.017 \\
3250 & 0.069 & 0.038 & 0.028 & 0.021 & 0.016 & 0.007 & 0.015 & 0.010 & 0.011 & 0.008 \\
3750 & 0.025 & 0.016 & 0.028 & 0.019 & 0.015 & 0.007 & 0.011 & 0.008 & 0.008 & 0.006 \\
4250 & 0.029 & 0.006 & 0.010 & 0.008 & 0.009 & 0.007 & 0.004 & 0.003 & 0.003 & 0.002 \\
4750 & 0.013 & 0.011 & 0.007 & 0.005 & 0.007 & 0.005 & 0.006 & 0.003 & 0.004 & 0.002
\end{tabular}


https://doi.org/10.5194/acp-2021-1100

Preprint. Discussion started: 7 January 2022

(c) Author(s) 2022. CC BY 4.0 License.

Table A2. Average and median $N_{\mathrm{BC}}$ from HALO observations. Values in column altitude represent centre of corresponding $500 \mathrm{~m}$ altitude bin.

\begin{tabular}{lllll}
\hline & \multicolumn{2}{c}{ EMeRGe EU } & \multicolumn{2}{c}{ BLUESKY } \\
& \multicolumn{2}{c}{ Observation } & \multicolumn{2}{c}{ Observation } \\
Altitude & Avg & Median & Avg & Median \\
{$[\mathrm{m}]$} & {$\left[\mathrm{cm}^{-3}\right]$} & {$\left[\mathrm{cm}^{-3}\right]$} & {$\left[\mathrm{cm}^{-3}\right]$} & {$\left[\mathrm{cm}^{-3}\right]$} \\
250 & 41.1 & 40.3 & 47.1 & 48.5 \\
750 & 81.8 & 65.4 & 31.8 & 27.0 \\
1250 & 62.5 & 53.1 & 33.7 & 30.7 \\
1750 & 75.3 & 52.3 & 22.9 & 19.3 \\
2250 & 54.2 & 15.0 & 18.0 & 5.1 \\
2750 & 45.0 & 15.6 & 8.6 & 3.5 \\
3250 & 34.4 & 25.8 & 4.7 & 2.4 \\
3750 & 10.2 & 6.0 & 4.1 & 2.4 \\
4250 & 10.8 & 4.7 & 4.2 & 3.2 \\
4750 & 4.6 & 2.9 & 3.2 & 2.6
\end{tabular}


https://doi.org/10.5194/acp-2021-1100

Preprint. Discussion started: 7 January 2022

(C) Author(s) 2022. CC BY 4.0 License.

Table A3. Average and median of $M_{\mathrm{BC}}$ microphysical properties, geometric mean diameters $\left(D_{\mathrm{rBC}}\right)$ and the geometric standard deviation $\left(\sigma_{\mathrm{rBC}}\right)$ of the core size distributions. Values in column altitude represent centre of corresponding $500 \mathrm{~m}$ altitude bin.

\begin{tabular}{llllllllll}
\hline & \multicolumn{4}{c}{ EMeRGe EU } & \multicolumn{3}{c}{ BLUESKY } \\
& \multicolumn{3}{c}{$D_{\mathrm{rBC}}$} & \multicolumn{2}{c}{$\sigma_{\mathrm{rBC}}$} & \multicolumn{2}{c}{$D_{\mathrm{rBC}}$} & \multicolumn{2}{c}{$\sigma_{\mathrm{rBC}}$} \\
Altitude & Avg & Median & Avg & Median & Avg & Median & Avg & Median \\
{$[\mathrm{m}]$} & {$[\mathrm{nm}]$} & {$[\mathrm{nm}]$} & & & {$[\mathrm{nm}]$} & {$[\mathrm{nm}]$} & & \\
250 & 157 & 155 & 2.083 & 2.047 & 144 & 152 & 2.180 & 2.063 \\
750 & 167 & 150 & 2.006 & 1.966 & 134 & 140 & 2.268 & 2.108 \\
1250 & 171 & 172 & 1.924 & 1.900 & 148 & 150 & 2.149 & 2.124 \\
1750 & 174 & 157 & 1.872 & 1.858 & 138 & 138 & 2.027 & 1.972 \\
2250 & 150 & 148 & 1.826 & 1.789 & 125 & 122 & 1.917 & 1.954 \\
2750 & 155 & 153 & 1.749 & 1.714 & 151 & 165 & 1.866 & 1.907 \\
3250 & 159 & 158 & 1.808 & 1.803 & 115 & 134 & 1.731 & 1.642 \\
3750 & 169 & 174 & 1.701 & 1.735 & 130 & 134 & 1.642 & 1.634 \\
4250 & 174 & 178 & 1.645 & 1.663 & 157 & 157 & 1.444 & 1.444 \\
4750 & 170 & 160 & 1.447 & 1.463 & 157 & 148 & 1.392 & 1.405
\end{tabular}


https://doi.org/10.5194/acp-2021-1100

Preprint. Discussion started: 7 January 2022

(c) Author(s) 2022. CC BY 4.0 License.

Table A4. Vertically integrated $M_{\mathrm{BC}}$ burden per surface area. BLUESKY adjusted is the BLUESKY observation and the EMAC model retrieved adjustment (see section A6). Values in column altitude represent centre of corresponding $500 \mathrm{~m}$ altitude bin. Pressure altitude scaling factor calculated as described in section A8. Last row provides column sum of vertically integrated $M_{\mathrm{BC}}$ burden.

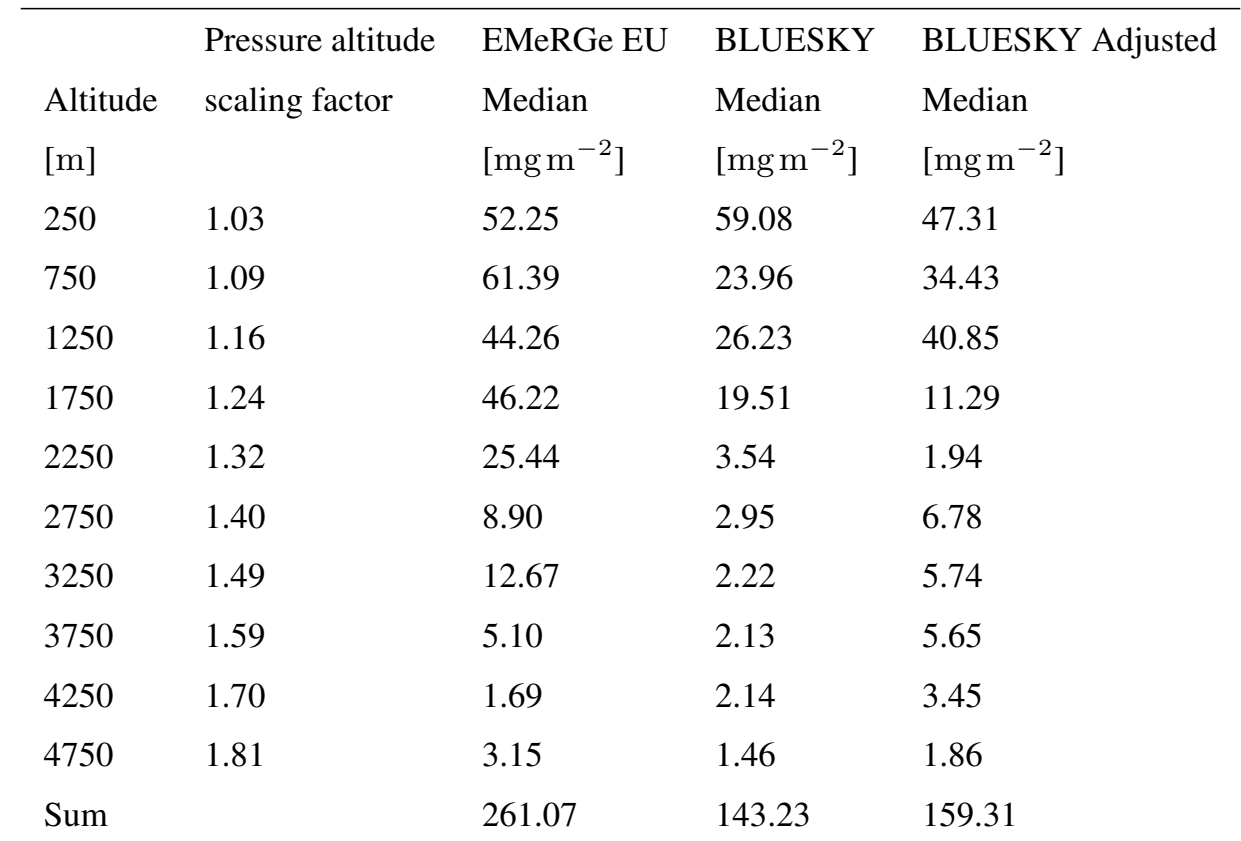




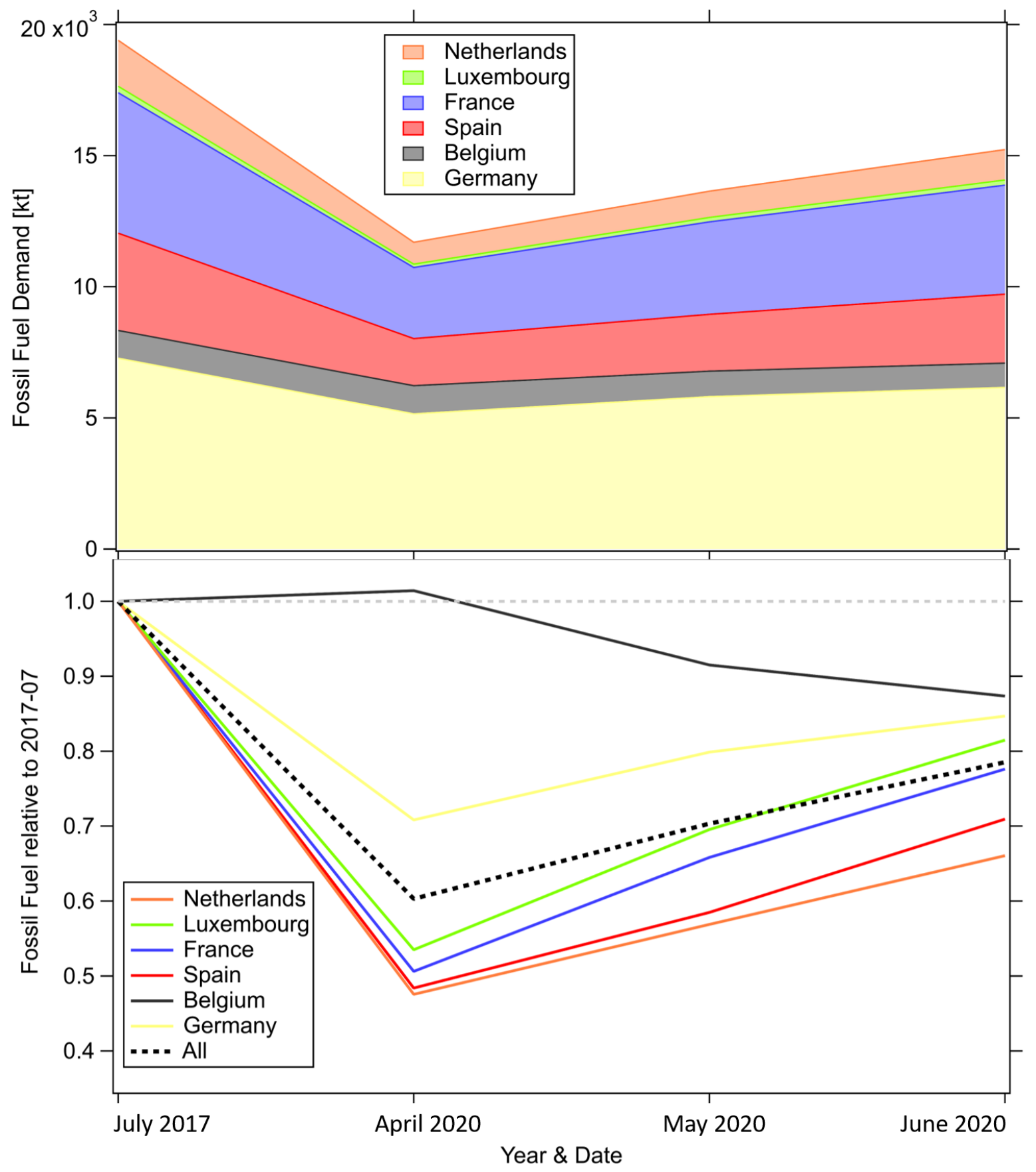

Figure A1. Cumulative EUROSTAT data for fossil fuel demand for the July 2017, April 2020, May 2020 and June 2020. The data combines demand for diesel, kerosene and motor spirit. Data is downloaded for countries considered in this study from the EUROSTAT website with last access 08.07.2021 (https://ec.europa.eu/eurostat/databrowser/view/NRG_CB_SFF_custom_1131819/default/table). 


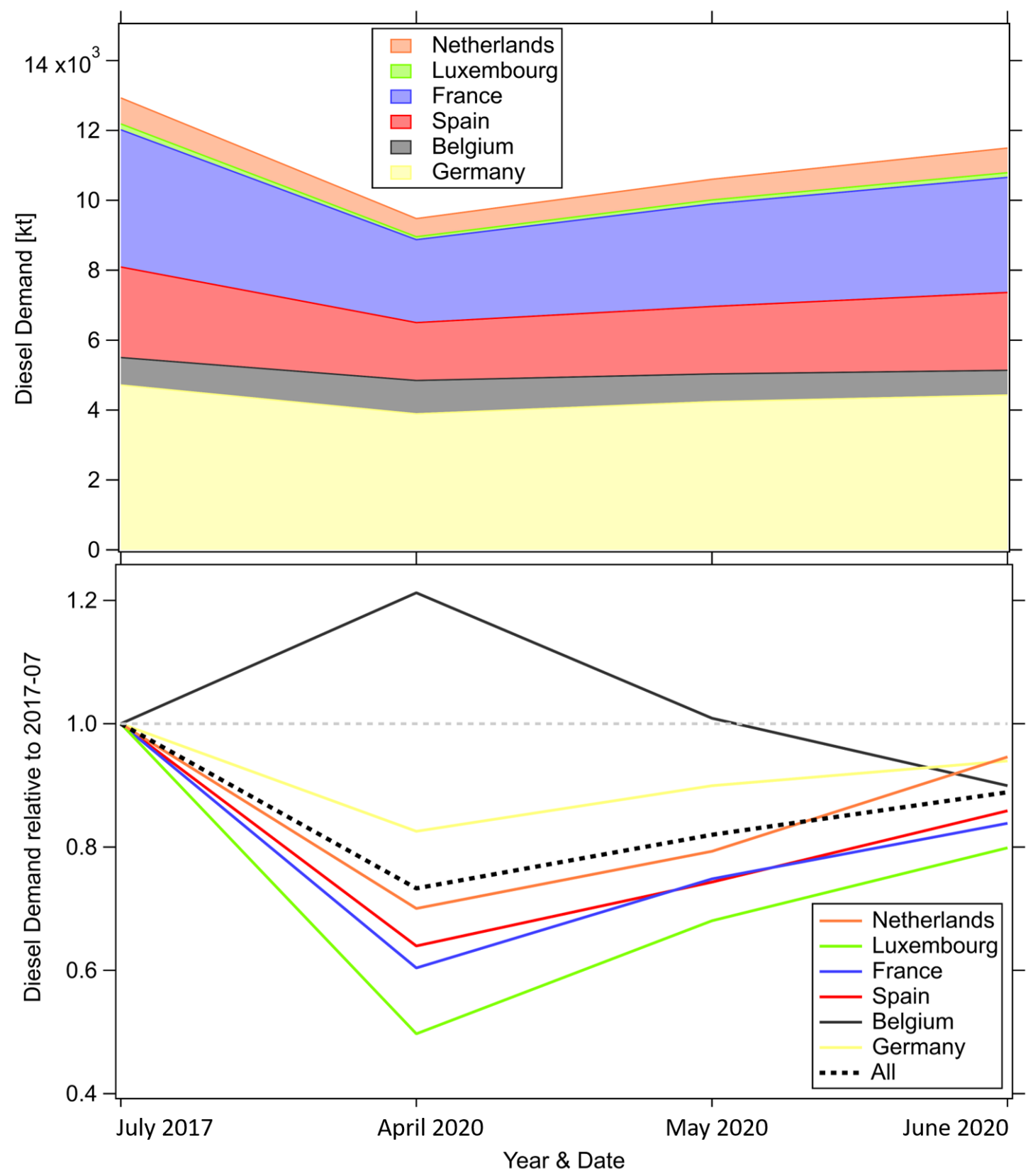

Figure A2. Cumulative EUROSTAT data for diesel demand for July 2017, April 2020, May 2020 and June 2020. The data combines demand for diesel, kerosene and motor spirit. Data is downloaded for countries considered in this study from the EUROSTAT website with last access 08.07.2021 (https://ec.europa.eu/eurostat/databrowser/view/NRG_CB_SFF_custom_1131819/default/table). 


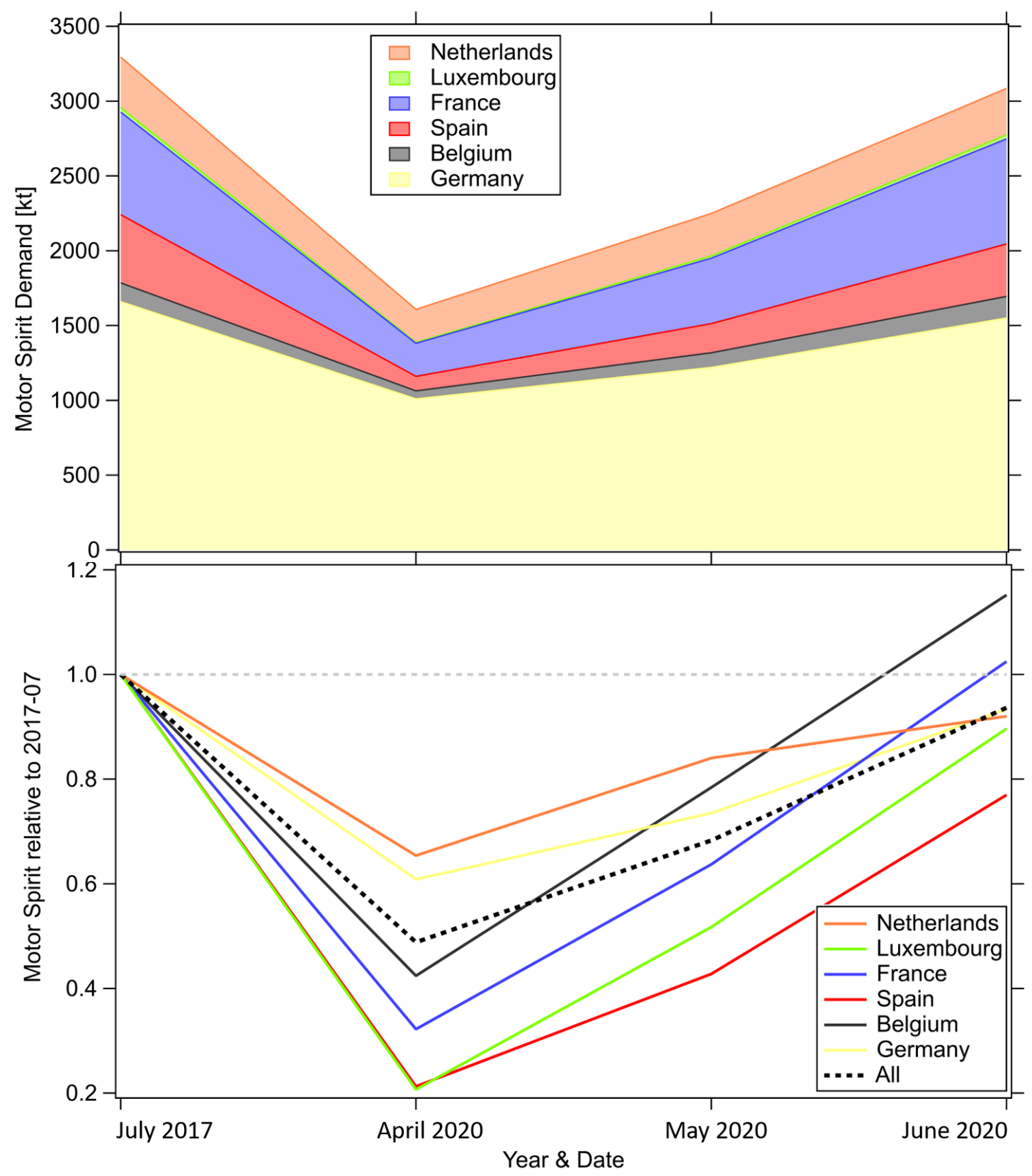

Figure A3. Cumulative EUROSTAT data for motor spirit demand for the July 2017, April 2020, May 2020 and June 2020. The data combines demand for diesel, kerosene and motor spirit. Data is downloaded for countries considered in this study from the EUROSTAT website with last access 08.07.2021 (https://ec.europa.eu/eurostat/databrowser/view/NRG_CB_SFF_custom_1131819/default/table). 


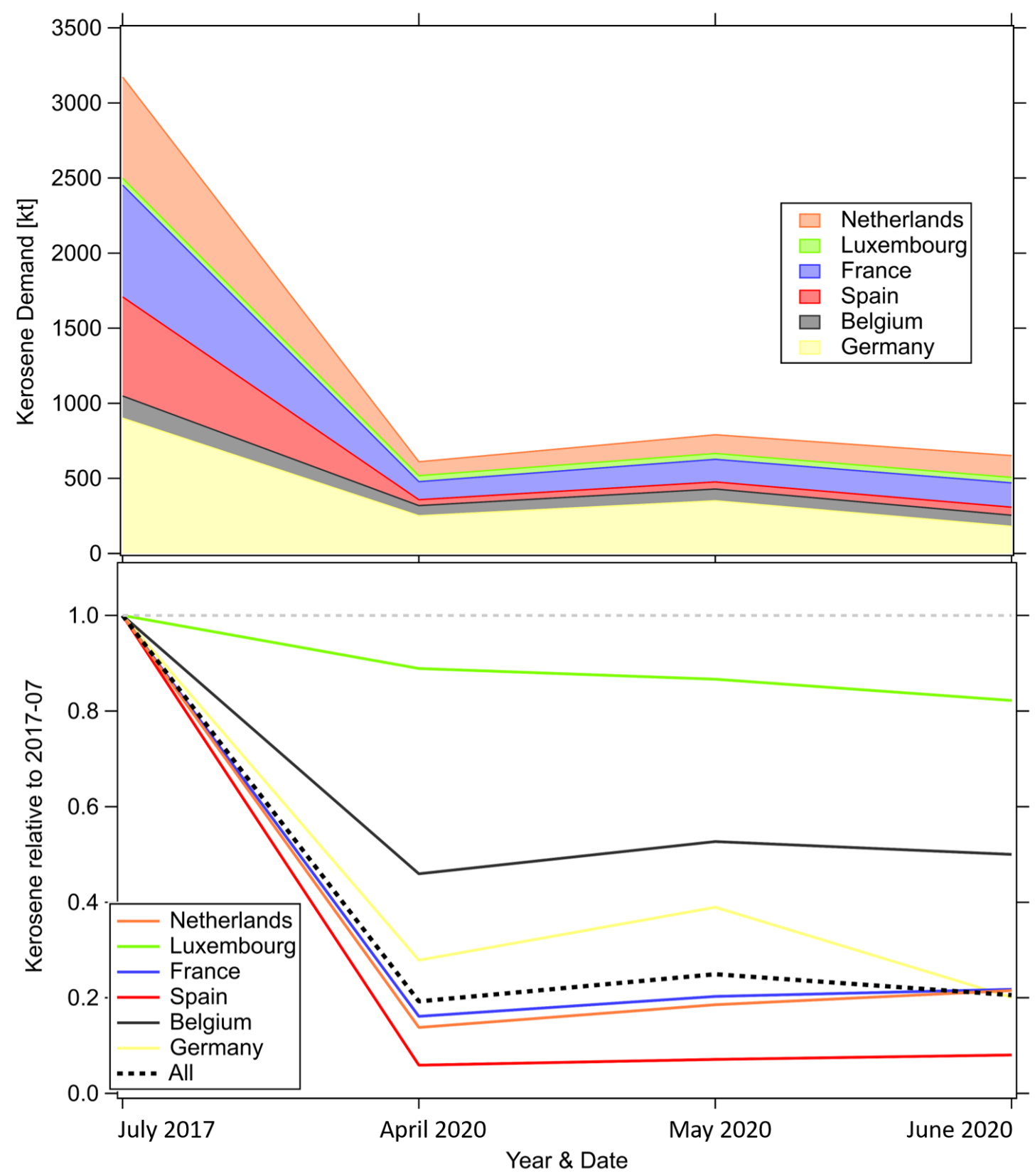

Figure A4. Cumulative EUROSTAT data for kerosene demand for the July 2017, April 2020, May 2020 and June 2020. The data combines demand for diesel, kerosene and motor spirit. Data is downloaded for countries considered in this study from the EUROSTAT website with last access 08.07.2021 (https://ec.europa.eu/eurostat/databrowser/view/NRG_CB_SFF_custom_1131819/default/table). 

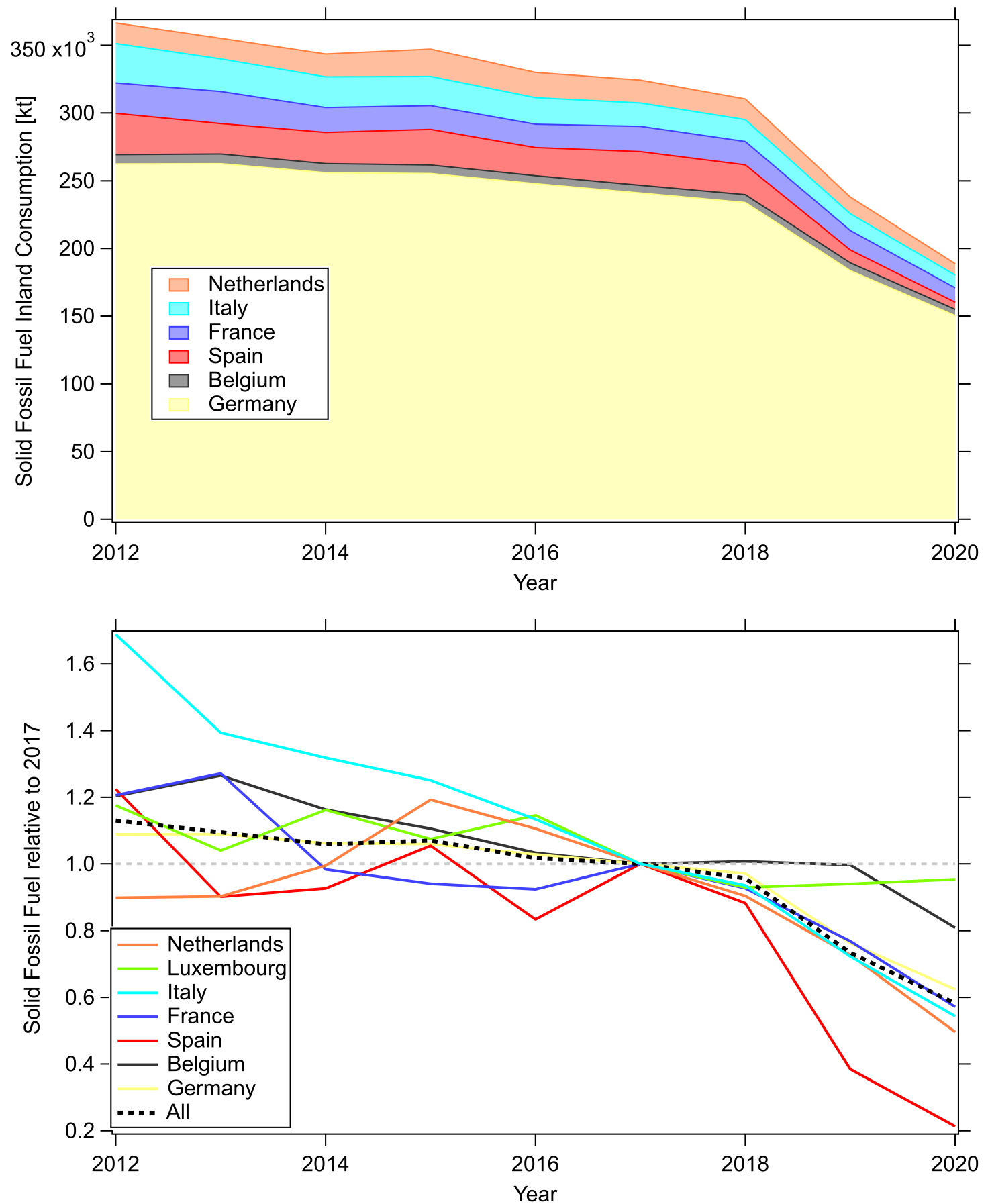

Figure A5. Cumulative EUROSTAT data for solid fossil fuel inland consumption for the years 2012 to 2020. Data is downloaded for countries considered in this study from the EUROSTAT website with last access 08.07.2021 (https://ec.europa.eu/eurostat/databrowser/view/ NRG_CB_SFF_custom_1131819/default/table). 
https://doi.org/10.5194/acp-2021-1100

Atmospheric

Chemistry

(c) Author(s) 2022. CC BY 4.0 License.

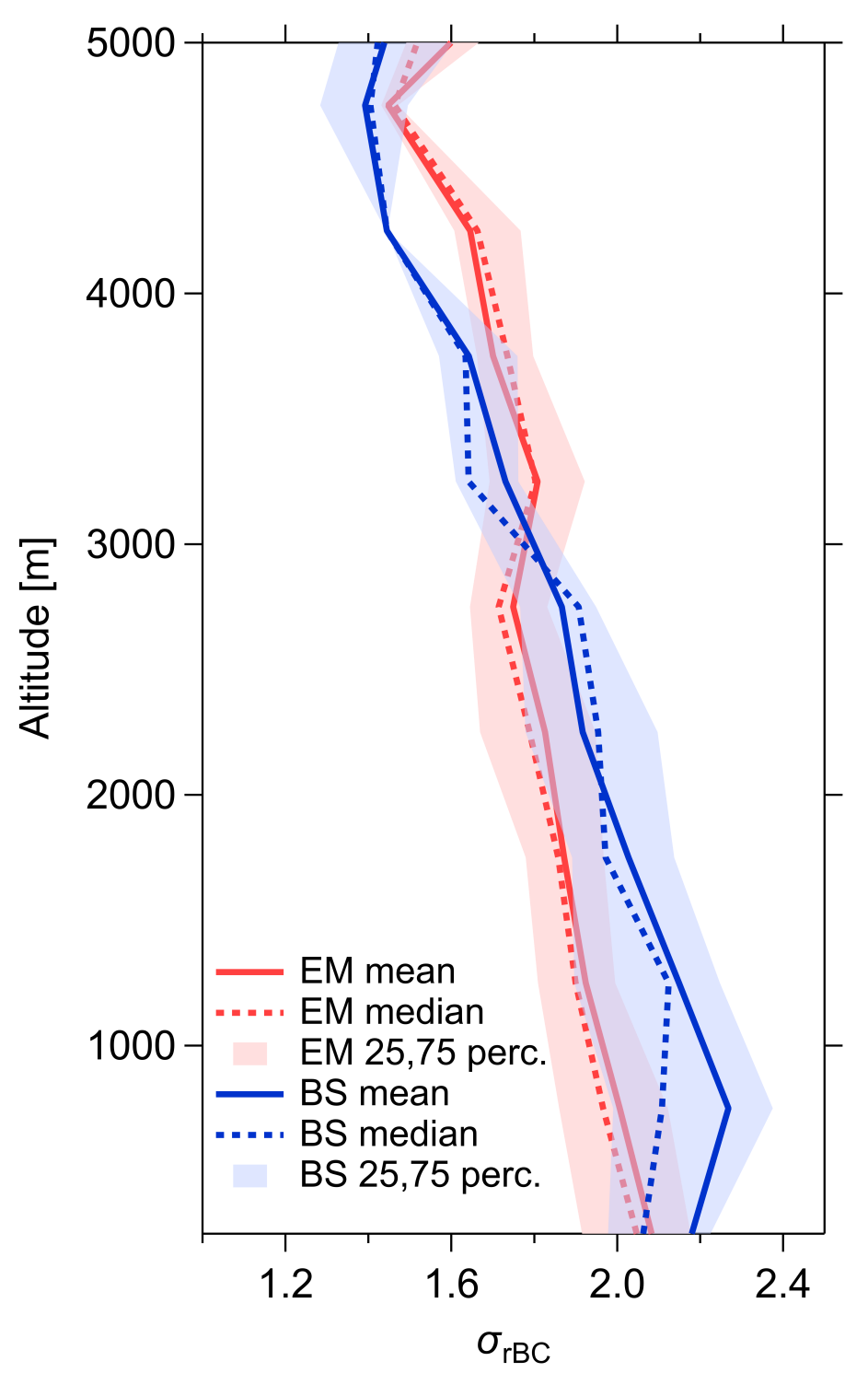

Figure A6. Vertical profiles of $M_{\mathrm{BC}}$ microphysical properties, the geometric standard deviation $\left(\sigma_{\mathrm{rBC}}\right)$ of the core size distributions. 2020 BLUESKY measurements in blue and 2017 EMeRGe EU measurements in red. Dashed lines show the median, solid lines the mean concentration and shaded areas represent interquartile range for each altitude bin of $500 \mathrm{~m}$. 
https://doi.org/10.5194/acp-2021-1100

Preprint. Discussion started: 7 January 2022

(C) Author(s) 2022. CC BY 4.0 License.

(c) (i)

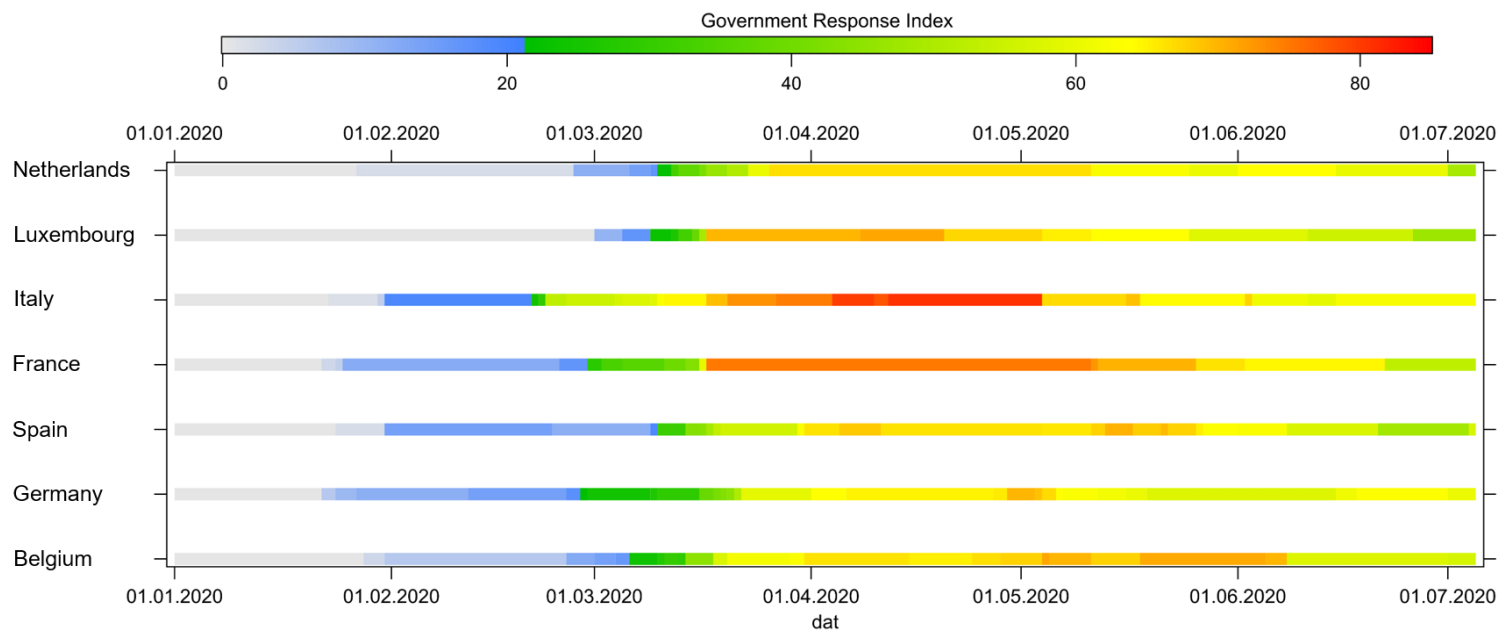

Figure A7. Temporal evolution of response on COVID-19 for selected European countries. Governmental response index data downloaded from https://github.com/OxCGRT/covid-policy-tracker/blob/3143b76020ef83072086853749c950ac0921ba47/data/timeseries/government_ response_index.csv, last access 06.07.2021. The governmental response index is described elsewhere (Hale et al., 2021). 
https://doi.org/10.5194/acp-2021-1100

Preprint. Discussion started: 7 January 2022

(C) Author(s) 2022. CC BY 4.0 License.

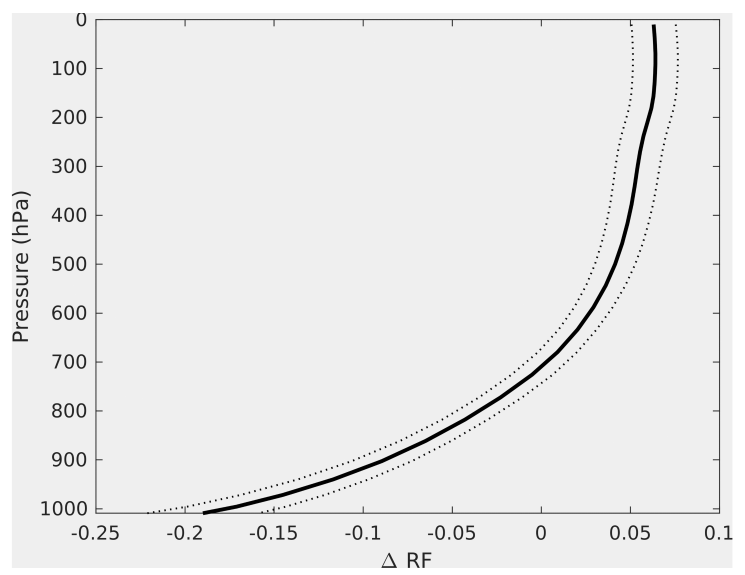

Figure A8. Profile for difference in aerosol radiative effect due to a reduction of $40 \%$ in $M_{\mathrm{BC}}$. The profile is averaged for the months May and June over the region of HALO measurements (latitude between -5 and $16^{\circ}$ and longitude between 37.5 and $54.5^{\circ}$, Fig. 1). 

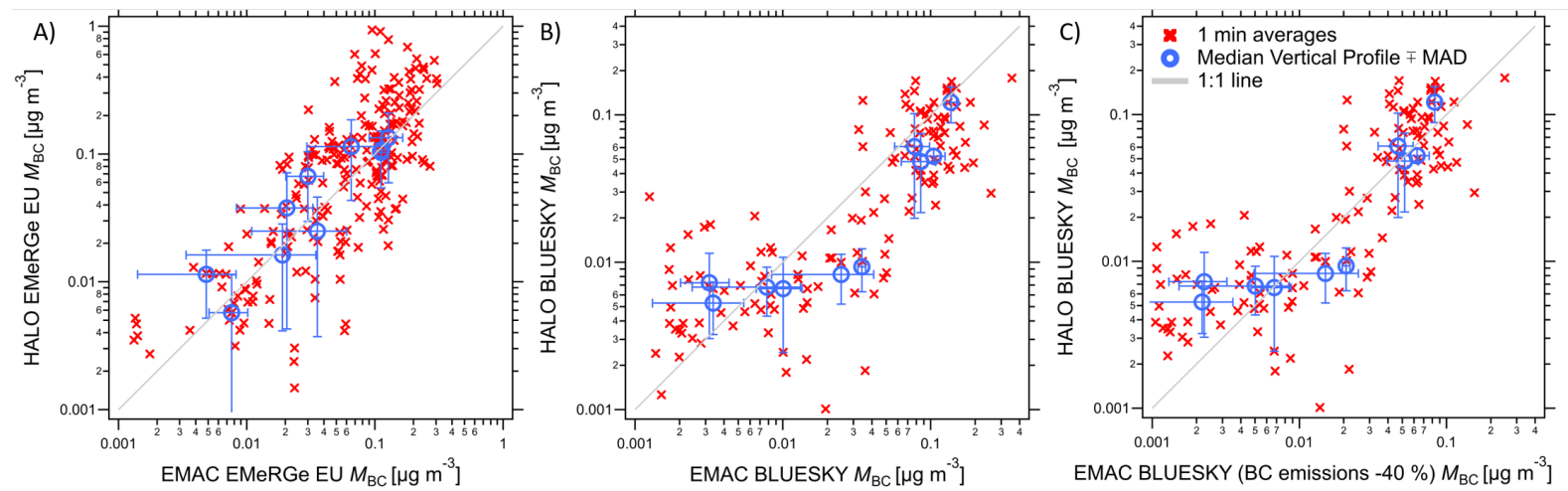

Figure A9. Scatter plot for median $M_{\mathrm{BC}}$ values of HALO measurements and EMAC model results. Red data shows the comparison of 1 minute averages. In blue median concentrations as used for the vertical profiles are shown. Error bars are one median absolute deviation (MAD) for the vertical merged data in $500 \mathrm{~m}$ altitude bins. Data shown is for the compared altitude up to $5000 \mathrm{~m}$. (A) corresponds to measurements from 2017 with $\mathrm{R}^{2}=0.84$. (B) are 2020 measurements with initial emissions in the EMAC model and $\mathrm{R}^{2}=0.88$. $(\mathrm{C})$ as $(\mathrm{B})$ but with $40 \%$ reduced anthropogenic emissions in EMAC simulation and $\mathrm{R}^{2}=0.88$. Note that the different ranges for $M_{\mathrm{BC}}$, (A) starts at $0.001 \mu \mathrm{g} / \mathrm{m}^{3}$ and the maximum is $1 \mu \mathrm{g} / \mathrm{m}^{3}$, whereas for BLUESKY (B and C) we did not observe $M_{\mathrm{BC}}$ exceeding $0.4 \mu \mathrm{g} / \mathrm{m}^{3}$ which defines the axis ranges. 
https://doi.org/10.5194/acp-2021-1100

Preprint. Discussion started: 7 January 2022

(c) Author(s) 2022. CC BY 4.0 License.

(c) (i)

\begin{tabular}{l} 
Atmospheric \\
Chemistry \\
and Physics \\
\hline Discussions \\
变 \\
on
\end{tabular}
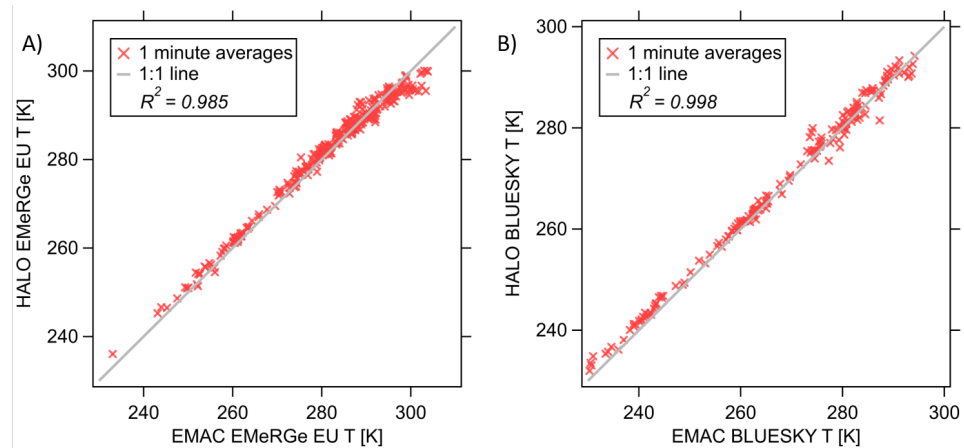

Figure A10. Scatter plot for ambient temperature $(\mathrm{T})$ in K from HALO measurements and EMAC model simulations. Grey line is the one to one ratio. (A) corresponds to measurements from 2017 with $R^{2}=0.985$. (B) are 2020 measurements with $R^{2}=0.998$. 
https://doi.org/10.5194/acp-2021-1100

Preprint. Discussion started: 7 January 2022

(C) Author(s) 2022. CC BY 4.0 License.

(c) (1)

Author contributions. MLP, BAH and OOK designed the study. BAH and OOK collected the HALO measurement data. OOK, BAH, DW, JL, $\mathrm{CV}$, MDAH and JPB played key roles in the collection and analysis of the data in the course of the HALO EMeRGe EU and BLUESKY campaigns. SC and AP conducted the EMAC simulations. JQ supported with the data interpretation and validation. OOK wrote the manuscript with contributions of all authors. All authors contributed to the discussion of the results as well as the finalization of the manuscript. UP and MLP supervised the study.

Competing interests. The authors declare that they have no conflict of interest.

Acknowledgements. We thank all people involved in the technical, logistical, and scientific support of the EMeRGe EU and BLUESKY HALO missions, in particular Katharina Kaiser, Daniel Sauer, Thomas Klimach, Vladyslav Nenakhov, Thomas Leder, the DLR flight department for support during the campaign and the pilots for excellent flight operations. Further, we thank Gerhard Lammel for fruitful discussions. Support by the Max-Planck-Society and by the German Science Foundation DFG within the SPP HALO 1294 is greatly appreciated. 


\section{References}

Andreae, M. O.: Aerosols Before Pollution, Science, 315, 50-51, https://doi.org/10.1126/science.1136529, 2007.

Andreae, M. O., Afchine, A., Albrecht, R., Holanda, B. A., Artaxo, P., Barbosa, H. M. J., Borrmann, S., Cecchini, M. A., Costa, A., Dollner, M., Fütterer, D., Järvinen, E., Jurkat, T., Klimach, T., Konemann, T., Knote, C., Krämer, M., Krisna, T., Machado, L. A. T., Mertes, S., Minikin, A., Pöhlker, C., Pöhlker, M. L., Pöschl, U., Rosenfeld, D., Sauer, D., Schlager, H., Schnaiter, M., Schneider, J., Schulz, C., Spanu, A., Sperling, V. B., Voigt, C., Walser, A., Wang, J., Weinzierl, B., Wendisch, M., and Ziereis, H.: Aerosol characteristics and particle production in the upper troposphere over the Amazon Basin, Atmospheric Chemistry and Physics, 18, 921-961, https://doi.org/10.5194/acp18-921-2018, https://www.atmos-chem-phys.net/18/921/2018/, 2018.

Andrés Hernández, M. D., Hilboll, A., Ziereis, H., Förster, E., Krüger, O. O., Kaiser, K., Schneider, J., Barnaba, F., Vrekoussis, M., Schmidt, J., Huntrieser, H., Blechschmidt, A.-M., George, M., Nenakhov, V., Klausner, T., Holanda, B. A., Wolf, J., Eirenschmalz, L., Krebsbach, M., Pöhlker, M. L., Hedegaard, A. B., Mei, L., Pfeilsticker, K., Liu, Y., Koppmann, R., Schlager, H., Bohn, B., Schumann, U., Richter, A., Schreiner, B., Sauer, D., Baumann, R., Mertens, M., Jöckel, P., Kilian, M., Stratmann, G., Pöhlker, C., Campanelli, M., Pandolfi, M., Sicard, M., Gomez-Amo, J. L., Pujadas, M., Bigge, K., Kluge, F., Schwarz, A., Daskalakis, N., Walter, D., Zahn, A., Pöschl, U., Bönisch, H., Borrmann, S., Platt, U., and Burrows, J. P.: Overview: On the transport and transformation of pollutants in the outflow of major population centres - observational data from the EMeRGe European intensive operational period in summer 2017, Atmospheric Chemistry and Physics Discussions, 2021, 1-81, https://doi.org/10.5194/acp-2021-500, https://acp.copernicus.org/preprints/acp-2021-500/, 2021.

Beer, C. G., Hendricks, J., Righi, M., Heinold, B., Tegen, I., Groß, S., Sauer, D., Walser, A., and Weinzierl, B.: Modelling mineral dust emissions and atmospheric dispersion with MADE3 in EMAC v2.54, Geosci. Model Dev., 13, 4287-4303, https://doi.org/10.5194/gmd13-4287-2020, 2020.

Bond, T. C., Doherty, S. J., Fahey, D. W., Forster, P. M., Berntsen, T., Deangelo, B. J., Flanner, M. G., Ghan, S., Kärcher, B., Koch, D., Kinne, S., Kondo, Y., Quinn, P. K., Sarofim, M. C., Schultz, M. G., Schulz, M., Venkataraman, C., Zhang, H., Zhang, S., Bellouin, N., Guttikunda, S. K., Hopke, P. K., Jacobson, M. Z., Kaiser, J. W., Klimont, Z., Lohmann, U., Schwarz, J. P., Shindell, D., Storelvmo, T., Warren, S. G., and Zender, C. S.: Bounding the role of black carbon in the climate system: A scientific assessment, Journal of Geophysical Research Atmospheres, 118, 5380-5552, https://doi.org/10.1002/jgrd.50171, 2013.

Brühl, C., Lelieveld, J., Tost, H., Höpfner, M., and Glatthor, N.: Stratospheric sulfur and its implications for radiative forcing simulated by the chemistry climate model EMAC, J Geophys Res Atmos, 120, 2103-2118, https://doi.org/10.1002/2014JD022430, 2015.

CIESIN: Center for International Earth Science Information Network - CIESIN - Columbia University. 2018. Gridded Population of the World, Version 4 (GPWv4): Population Density, Revision 11. Palisades, NY: NASA Socioeconomic Data and Applications Center (SEDAC). Accessed 24 October 2021., https://doi.org/10.7927/H49C6VHW, 2018.

Dietmüller, S., Jöckel, P., Tost, H., Kunze, M., Gellhorn, C., Brinkop, S., Frömming, C., Ponater, M., Steil, B., Lauer, A., and Hendricks, J.: A new radiation infrastructure for the Modular Earth Submodel System (MESSy, based on version 2.51), Geosci Model Dev, 9, 2209-2222, https://doi.org/10.5194/gmd-9-2209-2016, 2016.

Ditas, J., Ma, N., Zhang, Y., Assmann, D., Neumaier, M., Riede, H., Karu, E., Williams, J., Scharffe, D., Wang, Q., Saturno, J., Schwarz, J. P., Katich, J. M., McMeeking, G. R., Zahn, A., Hermann, M., Brenninkmeijer, C. A. M., Andreae, M. O., Pöschl, U., Su, H., and Cheng, Y.: Strong impact of wildfires on the abundance and aging of black carbon in the lowermost stratosphere, Proceedings of the National Academy of Sciences, 115, E11 595-E11 603, https://doi.org/10.1073/pnas.1806868115, https://www.pnas.org/content/115/50/E11595, 2018. 
Evangeliou, N., Platt, S. M., Eckhardt, S., Lund Myhre, C., Laj, P., Alados-Arboledas, L., Backman, J., Brem, B. T., Fiebig, M., Flentje, H., Marinoni, A., Pandolfi, M., Yus-Dìez, J., Prats, N., Putaud, J. P., Sellegri, K., Sorribas, M., Eleftheriadis, K., Vratolis, S., Wiedensohler, A., and Stohl, A.: Changes in black carbon emissions over Europe due to COVID-19 lockdowns, Atmospheric Chemistry and Physics, 21, 2675-2692, https://doi.org/10.5194/acp-21-2675-2021, 2021.

Forster, P. M., Forster, H. I., Evans, M. J., Gidden, M. J., Jones, C. D., Keller, C. A., Lamboll, R. D., Quéré, C. L., Rogelj, J., Rosen, D., Schleussner, C. F., Richardson, T. B., Smith, C. J., and Turnock, S. T.: Current and future global climate impacts resulting from COVID-19, Nature Climate Change, 10, 913-919, https://doi.org/10.1038/s41558-020-0883-0, 2020.

Gustafsson, Ö. and Ramanathan, V.: Convergence on climate warming by black carbon aerosols, Proceedings of the National Academy of Sciences of the United States of America, 113, 4243-4245, https://doi.org/10.1073/pnas.1603570113, 2016.

Gysel-Beer, M. and Corbin, J.: SP2 toolkit 4.115 (Igor7) (Version 4.115), http://doi.org/10.5281/zenodo.3575186/, 2019.

Hale, T., Angrist, N., Goldszmidt, R., Kira, B., Petherick, A., Phillips, T., Webster, S., Cameron-Blake, E., Hallas, L., Majumdar, S., and Tatlow, H.: A global panel database of pandemic policies (Oxford COVID-19 Government Response Tracker), Nature Human Behaviour, 5, 529-538, https://doi.org/10.1038/s41562-021-01079-8, http://dx.doi.org/10.1038/s41562-021-01079-8, 2021.

Heald, C. L., Ridley, D. A., Kroll, J. H., Barrett, S. R., Cady-Pereira, K. E., Alvarado, M. J., and Holmes, C. D.: Contrasting the direct radiative effect and direct radiative forcing of aerosols, Atmospheric Chemistry and Physics, 14, 5513-5527, https://doi.org/10.5194/acp14-5513-2014, 2014.

Heintzenberg, J.: Properties of the log-normal particle size distribution, Aerosol Science and Technology, 21, 46-48, https://doi.org/10.1080/02786829408959695, 1994.

Hoesly, R. M., Smith, S. J., Feng, L., Klimont, Z., Janssens-Maenhout, G., Pitkanen, T., Seibert, J. J., Vu, L., Andres, R. J., Bolt, R. M., Bond, T. C., Dawidowski, L., Kholod, N., Kurokawa, J.-i., Li, M., Liu, L., Lu, Z., Moura, M. C. P., O’Rourke, P. R., and Zhang, Q.: Historical (1750-2014) anthropogenic emissions of reactive gases and aerosols from the Community Emissions Data System (CEDS), Geosci. Model Dev., 11, 369-408, https://doi.org/10.5194/gmd-11-369-2018, 2018.

Holanda, B. A., Pöhlker, M. L., Walter, D., Saturno, J., Sörgel, M., Ditas, J., Ditas, F., Schulz, C., Aurélio Franco, M., Wang, Q., Donth, T., Artaxo, P., Barbosa, H. M., Borrmann, S., Braga, R., Brito, J., Cheng, Y., Dollner, M., Kaiser, J. W., Klimach, T., Knote, C., Krüger, O. O., Fütterer, D., t.V. Lavric, J., Ma, N., MacHado, L. A., Ming, J., Morais, F. G., Paulsen, H., Sauer, D., Schlager, H., Schneider, J., Su, H., Weinzierl, B., Walser, A., Wendisch, M., Ziereis, H., Zöger, M., Pöschl, U., Andreae, M. O., and Pöhlker, C.: Influx of African biomass burning aerosol during the Amazonian dry season through layered transatlantic transport of black carbon-rich smoke, Atmospheric Chemistry and Physics, 20, 4757-4785, https://doi.org/10.5194/acp-20-4757-2020, 2020.

Jöckel, P., Sander, R., Kerkweg, A., Tost, H., and Lelieveld, J.: Technical Note: The Modular Earth Submodel System (MESSy) - a new approach towards Earth System Modeling, Atmos. Chem. Phys., 5, 433-444, https://doi.org/10.5194/acp-5-433-2005, 2005.

Jöckel, P., Kerkweg, A., Pozzer, A., Sander, R., Tost, H., Riede, H., Baumgaertner, A., Gromov, S., and Kern, B.: Development cycle 2 of the Modular Earth Submodel System (MESSy2), Geosci. Model Dev., 3, 717-752, https://doi.org/10.5194/gmd-3-717-2010, 2010.

Kaiser, J. W., Heil, A., Andreae, M. O., Benedetti, A., Chubarova, N., Jones, L., Morcrette, J.-J., Razinger, M., Schultz, M. G., Suttie, M., and van der Werf, G. R.: Biomass burning emissions estimated with a global fire assimilation system based on observed fire radiative power, Biogeosciences, 9, 527-554, https://doi.org/10.5194/bg-9-527-2012, 2012.

Kerkweg, A., Sander, R., Tost, H., and Jöckel, P.: Technical note: Implementation of prescribed (OFFLEM), calculated (ONLEM), and pseudo-emissions (TNUDGE) of chemical species in the Modular Earth Submodel System (MESSy), Atmos. Chem. Phys., 6, 36033609, https://doi.org/10.5194/acp-6-3603-2006, 2006. 
Klingmüller, K., Lelieveld, J., Karydis, V. A., and Stenchikov, G. L.: Direct radiative effect of dust-pollution interactions, Atmos Chem Phys, 19, 7397-7408, https://doi.org/10.5194/acp-19-7397-2019, 2019.

Kutzner, R. D., von Schneidemesser, E., Kuik, F., Quedenau, J., Weatherhead, E. C., and Schmale, J.: Long-term monitoring of black carbon across Germany, Atmospheric Environment, 185, 41-52, https://doi.org/https://doi.org/10.1016/j.atmosenv.2018.04.039, https:// www.sciencedirect.com/science/article/pii/S135223101830270X, 2018.

Laborde, M., Schnaiter, M., Linke, C., Saathoff, H., Naumann, K.-H., Möhler, O., Berlenz, S., Wagner, U., Taylor, J. W., Liu, D., Flynn, M., Allan, J. D., Coe, H., Heimerl, K., Dahlkötter, F., Weinzierl, B., Wollny, A. G., Zanatta, M., Cozic, J., Laj, P., Hitzenberger, R., Schwarz, J. P., and Gysel, M.: Single Particle Soot Photometer intercomparison at the AIDA chamber, Atmospheric Measurement Techniques, 5, 3077-3097, https://doi.org/10.5194/amt-5-3077-2012, 2012.

Laborde, M., Crippa, M., Tritscher, T., Jurányi, Z., Decarlo, P. F., Temime-Roussel, B., Marchand, N., Eckhardt, S., Stohl, A., Baltensperger, U., Prévôt, A. S., Weingartner, E., and Gysel, M.: Black carbon physical properties and mixing state in the European megacity Paris, Atmospheric Chemistry and Physics, 13, 5831-5856, https://doi.org/10.5194/acp-13-5831-2013, 2013.

Lauer, A., Eyring, V., Hendricks, J., Jöckel, P., and Lohmann, U.: Global model simulations of the impact of ocean-going ships on aerosols, clouds, and the radiation budget, Atmos Chem Phys, 7, 5061-5079, https://doi.org/10.5194/acp-7-5061-2007, 2007.

Le Quéré, C., Jackson, R. B., Jones, M. W., Smith, A. J., Abernethy, S., Andrew, R. M., De-Gol, A. J., Willis, D. R., Shan, Y., Canadell, J. G., Friedlingstein, P., Creutzig, F., and Peters, G. P.: Temporary reduction in daily global CO2 emissions during the COVID-19 forced confinement, Nature Climate Change, 10, 647-653, https://doi.org/10.1038/s41558-020-0797-x, http://dx.doi.org/10.1038/s41558-020-0797-x, 2020.

Lelieveld, J., Brühl, C., Jöckel, P., Steil, B., Crutzen, P. J., Fischer, H., Giorgetta, M. A., Hoor, P., Lawrence, M. G., Sausen, R., and Tost, H.: Stratospheric dryness: model simulations and satellite observations, Atmos Chem Phys, 7, 1313-1332, https://doi.org/10.5194/acp-71313-2007, 2007.

Lelieveld, J., Klingmueller, K., Pozzer, A., Burnett, R. T., Haines, A., and Ramanathan, V.: Effects of fossil fuel and total anthropogenic emission removal on public health and climate, Proc Natl Acad Sci U.S.A, 116, 7192-7197, https://doi.org/10.1073/pnas.1819989116, 2019.

Li, Q. and Groß, S.: Changes of cirrus cloud properties and occurrence over Europe during the COVID-19 caused air traffic reduction, Atmospheric Chemistry and Physics Discussions, pp. 1-25, https://doi.org/10.5194/acp-2021-172, 2021.

Liu, D., Allan, J. D., Young, D. E., Coe, H., Beddows, D., Fleming, Z. L., Flynn, M. J., Gallagher, M. W., Harrison, R. M., Lee, J., Prevot, A. S., Taylor, J. W., Yin, J., Williams, P. I., and Zotter, P.: Size distribution, mixing state and source apportionment of black carbon aerosol in London during winter time, Atmospheric Chemistry and Physics, 14, 10 061-10 084, https://doi.org/10.5194/acp-14-10061-2014, 2014.

Lonati, G. and Riva, F.: Regional scale impact of the covid-19 lockdown on air quality: Gaseous pollutants in the po valley, northern Italy, Atmosphere, 12, https://doi.org/10.3390/atmos12020264, 2021.

Lund, M. T., Samset, B. H., Skeie, R. B., Watson-Parris, D., Katich, J. M., Schwarz, J. P., and Weinzierl, B.: Short Black Carbon lifetime inferred from a global set of aircraft observations, npj Climate and Atmospheric Science, 1, 1-8, https://doi.org/10.1038/s41612-0180040-x, http://dx.doi.org/10.1038/s41612-018-0040-x, 2018.

McDuffie, E. E., Smith, S. J., O’Rourke, P., Tibrewal, K., Venkataraman, C., Marais, E. A., Zheng, B., Crippa, M., Brauer, M., and Martin, R. V.: A global anthropogenic emission inventory of atmospheric pollutants from sector- and fuel-specific sources (1970-2017): an application of the Community Emissions Data System (CEDS), Earth System Science Data, 12, 3413-3442, https://doi.org/10.5194/essd12-3413-2020, https://essd.copernicus.org/articles/12/3413/2020/, 2020. 
Moreda-Piñeiro, J., Sánchez-Piñero, J., Fernández-Amado, M., Costa-Tomé, P., Gallego-Fernández, N., Piñeiro-Iglesias, M., LópezMahía, P., and Muniategui-Lorenzo, S.: Evolution of gaseous and particulate pollutants in the air: What changed after five lockdown weeks at a southwest atlantic european region (northwest of spain) due to the sars-cov-2 pandemic?, Atmosphere, 12, https://doi.org/10.3390/atmos12050562, 2021.

Naik, V., Szopa, S., Adhikary, B., Artaxo, P., Berntsen, T., Collins, W. D., Fuzzi, S., Gallardo, L., Kiendler Scharr, A., Klimont, Z., Liao, H., Unger, N., and Zanis, P.: Climate Change 2021: The Physical Science Basis. Contribution of Working Group I to the Sixth Assessment Report of the Intergovernmental Panel on Climate Change, Cambridge University Press, 2021. In Press.

Ohata, S., Moteki, N., Mori, T., Koike, M., and Kondo, Y.: A key process controlling the wet removal of aerosols: New observational evidence, Scientific Reports, 6, 1-9, https://doi.org/10.1038/srep34113, 2016.

Paasonen, P., Kupiainen, K., Klimont, Z., Visschedijk, A., Denier van der Gon, H. A. C., and Amann, M.: Continental anthropogenic primary particle number emissions, Atmos. Chem. Phys., 16, 6823-6840, https://doi.org/10.5194/acp-16-6823-2016, 2016.

Petetin, H., Bowdalo, D., Soret, A., Guevara, M., Jorba, O., Serradell, K., and Pérez García-Pando, C.: Meteorology-normalized impact of the COVID-19 lockdown upon NO2 pollution in Spain, Atmospheric Chemistry and Physics, 20, 11 119-11 141, https://doi.org/10.5194/acp20-11119-2020, 2020.

Pileci, R. E., Modini, R. L., Bertò, M., Yuan, J., Corbin, J. C., Marinoni, A., Henzing, B., Moerman, M. M., Putaud, J. P., Spindler, G., Wehner, B., Müller, T., Tuch, T., Trentini, A., Zanatta, M., Baltensperger, U., and Gysel-Beer, M.: Comparison of co-located refractory black carbon (rBC) and elemental carbon (EC) mass concentration measurements during field campaigns at several European sites, Atmospheric Measurement Techniques, 14, 1379-1403, https://doi.org/10.5194/amt-14-1379-2021, https://amt.copernicus.org/articles/14/1379/2021/, 2021.

Pöschl, U.: Atmospheric aerosols: Composition, transformation, climate and health effects, Angewandte Chemie - International Edition, 44, 7520-7540, https://doi.org/10.1002/anie.200501122, 2005.

Pozzer, A., de Meij, A., Pringle, K. J., Tost, H., Doering, U. M., van Aardenne, J., and Lelieveld, J.: Distributions and regional budgets of aerosols and their precursors simulated with the EMAC chemistry-climate model, Atmos. Chem. Phys., 12, 961-987, https://doi.org/10.5194/acp-12-961-2012, 2012.

Pozzer, A., de Meij, A., Yoon, J., Tost, H., Georgoulias, A. K., and Astitha, M.: AOD trends during 2001-2010 from observations and model simulations, Atmos Chem Phys, 15, 5521-5535, https://doi.org/10.5194/acp-15-5521-2015, 2015.

Pringle, K. J., Tost, H., Message, S., Steil, B., Giannadaki, D., Nenes, A., Fountoukis, C., Stier, P., Vignati, E., and Lelieveld, J.: Description and evaluation of GMXe: a new aerosol submodel for global simulations (v1), Geosci. Model Dev., 3, 391-412, https://doi.org/10.5194/gmd-3-391-2010, 2010.

Quaas, M. F., Meya, J. N., Schenk, H., Bos, B., Drupp, M. A., and Requate, T.: The social cost of contacts: Theory and evidence for the first wave of the COVID-19 pandemic in Germany, PLOS ONE, 16, 1-29, https://doi.org/10.1371/journal.pone.0248288, https://doi.org/ 10.1371/journal.pone.0248288, 2021a.

Quaas, M. F., Meya, J. N., Schenk, H., Bos, B., Drupp, M. A., and Requate, T.: The social cost of contacts: Theory and evidence for the first wave of the COVID-19 pandemic in Germany, PLOS ONE, 16, 1-29, https://doi.org/10.1371/journal.pone.0248288, https://doi.org/ 10.1371/journal.pone.0248288, 2021 b.

Querol, X., Alastuey, A., Viana, M., Moreno, T., Reche, C., Minguillón, M. C., Ripoll, A., Pandolfi, M., Amato, F., Karanasiou, A., Pérez, N., Pey, J., Cusack, M., Vázquez, R., Plana, F., Dall’Osto, M., de la Rosa, J., Sánchez de la Campa, A., Fernández-Camacho, R., Rodríguez, S., Pio, C., Alados-Arboledas, L., Titos, G., Artíñano, B., Salvador, P., García Dos Santos, S., and Fernández Patier, R.: Variability of carbona- 
ceous aerosols in remote, rural, urban and industrial environments in Spain: implications for air quality policy, Atmospheric Chemistry and Physics, 13, 6185-6206, https://doi.org/10.5194/acp-13-6185-2013, https://acp.copernicus.org/articles/13/6185/2013/, 2013.

Ramanathan, V. and Carmichael, G.: Global and regional climate changes due to black carbon, Nature Geoscience, 1, 221-227, https://doi.org/10.1038/ngeo156, 2008.

Reddington, C. L., McMeeking, G., Mann, G. W., Coe, H., Frontoso, M. G., Liu, D., Flynn, M., Spracklen, D. V., and Carslaw, K. S.: The mass and number size distributions of black carbon aerosol over Europe, Atmospheric Chemistry and Physics, 13, 4917-4939, https://doi.org/10.5194/acp-13-4917-2013, 2013.

S. Raj, S., Krüger, O. O., Sharma, A., Panda, U., Pöhlker, C., Walter, D., Förster, J.-D., Singh, R. P., S., S., Klimach, T., Darbyshire, E., Martin, S. T., McFiggans, G., Coe, H., Allan, J., R., R., Soni, V. K., Su, H., Andreae, M. O., Pöschl, U., Pöhlker, M. L., and Gunthe, S. S.: Planetary Boundary Layer Height Modulates Aerosol-Water Vapor Interactions During Winter in the Megacity of Delhi, Journal of Geophysical Research: Atmospheres, 126, e2021JD035 681, https://doi.org/https://doi.org/10.1029/2021JD035681, https://agupubs. onlinelibrary.wiley.com/doi/abs/10.1029/2021JD035681, e2021JD035681 2021JD035681, 2021.

Sander, R., Kerkweg, A., Jöckel, P., and Lelieveld, J.: Technical note: The new comprehensive atmospheric chemistry module MECCA, Atmos. Chem. Phys., 5, 445-450, https://doi.org/10.5194/acp-5-445-2005, 2005.

Sander, R., Baumgaertner, A., Cabrera-Perez, D., Frank, F., Gromov, S., Grooß, J.-U., Harder, H., Huijnen, V., Jöckel, P., Karydis, V. A., Niemeyer, K. E., Pozzer, A., Riede, H., Schultz, M. G., Taraborrelli, D., and Tauer, S.: The community atmospheric chemistry box model CAABA/MECCA-4.0, Geosci. Model Dev., 12, 1365-1385, https://doi.org/10.5194/gmd-12-1365-2019, 2019.

Schumann, U., Bugliaro, L., Dörnbrack, A., Baumann, R., and Voigt, C.: Aviation Contrail Cirrus and Radiative Forcing Over Europe During 6 Months of COVID-19, Geophysical Research Letters, 48, e2021GL092 771, https://doi.org/https://doi.org/10.1029/2021GL092771, https://agupubs.onlinelibrary.wiley.com/doi/abs/10.1029/2021GL092771, e2021GL092771 2021GL092771, 2021a.

Schumann, U., Poll, I., Teoh, R., Koelle, R., Spinielli, E., Molloy, J., Koudis, G. S., Baumann, R., Bugliaro, L., Stettler, M., and Voigt, C.: Air traffic and contrail changes during COVID-19 over Europe : A model study, Atmospheric Chemistry and Physics Discussions, pp. 1-37, https://doi.org/10.5194/acp-2021-62, 2021 b.

Schwarz, J. P., Gao, R. S., Fahey, D. W., Thomson, D. S., Watts, L. A., Wilson, J. C., Reeves, J. M., Darbeheshti, M., Baumgardner, D. G., Kok, G. L., Chung, S. H., Schulz, M., Hendricks, J., Lauer, A., Kärcher, B., Slowik, J. G., Rosenlof, K. H., Thompson, T. L., Langford, A. O., Loewenstein, M., and Aikin, K. C.: Single-particle measurements of midlatitude black carbon and light-scattering aerosols from the boundary layer to the lower stratosphere, Journal of Geophysical Research Atmospheres, 111, 1-15, https://doi.org/10.1029/2006JD007076, 2006.

Schwarz, J. P., Gao, R. S., Spackman, J. R., Watts, L. A., Thomson, D. S., Fahey, D. W., Ryerson, T. B., Peischl, J., Holloway, J. S., Trainer,

M., Frost, G. J., Baynard, T., Lack, D. A., de Gouw, J. A., Warneke, C., and Del Negro, L. A.: Measurement of the mixing state, mass, and optical size of individual black carbon particles in urban and biomass burning emissions, Geophysical Research Letters, 35, 1-5, https://doi.org/10.1029/2008GL033968, 2008.

Schwarz, J. P., Weinzierl, B., Samset, B. H., Dollner, M., Heimerl, K., Markovic, M. Z., Perring, A. E., and Ziemba, L.: Aircraft measurements of black carbon vertical profiles show upper tropospheric variability and stability, Geophysical Research Letters, 44, 1132-1140, https://doi.org/https://doi.org/10.1002/2016GL071241, https://agupubs.onlinelibrary.wiley.com/doi/abs/10.1002/2016GL071241, 2017.

Seinfeld, J. H. and Pandis, S. N.: Atmospheric Chemistry and Physics: From Air Pollution to Climate Change, John Wiley \& Sons, Inc., https://doi.org/10.1063/1.882420, 2006. 
Shi, Z., Song, C., Liu, B., Lu, G., Xu, J., Van Vu, T., Elliott, R. J., Li, W., Bloss, W. J., and Harrison, R. M.: Abrupt but smaller than expected changes in surface air quality attributable to COVID-19 lockdowns, Science Advances, 7, https://doi.org/10.1126/sciadv.abd6696, 2021.

Singh, V., Ravindra, K., Sahu, L., and Sokhi, R.: Trends of atmospheric black carbon concentration over the United Kingdom, Atmospheric Environment, 178, 148-157, https://doi.org/https://doi.org/10.1016/j.atmosenv.2018.01.030, https://www.sciencedirect.com/ science/article/pii/S135223101830044X, 2018.

Stephens, M., Turner, N., and Sandberg, J.: Particle identification by laser-induced incandescence in a solid-state laser cavity, Applied Optics, 42, 3726, https://doi.org/10.1364/ao.42.003726, 2003.

Tsimpidi, A. P., Karydis, V. A., Pozzer, A., Pandis, S. N., and Lelieveld, J.: ORACLE (v1.0): module to simulate the organic aerosol composition and evolution in the atmosphere, Geosci. Model Dev., 7, 3153-3172, https://doi.org/10.5194/gmd-7-3153-2014, 2014.

Tsimpidi, A. P., Karydis, V. A., Pozzer, A., Pandis, S. N., and Lelieveld, J.: ORACLE 2-D (v2.0): an efficient module to compute the volatility and oxygen content of organic aerosol with a global chemistry-climate model, Geosci. Model Dev., 11, 3369-3389, https://doi.org/10.5194/gmd-11-3369-2018, 2018.

Venter, Z. S., Aunan, K., Chowdhury, S., and Lelieveld, J.: COVID-19 lockdowns cause global air pollution declines, Proceedings of the National Academy of Sciences, 117, 18 984-18 990, https://doi.org/10.1073/pnas.2006853117, https://www.pnas.org/content/117/32/18984, 2020.

Voigt, C., Lelieveld, J., Schlager, H., Schneider, J., Curtius, J., Meerkötter, R., Sauer, D., Bugliaro, L., Bohn, B., Crowley, J., Erbertseder, T., Groß, S., Li, Q., Mertens, M., Pöhlker, M., Pozzer, A., Schumann, U., Tomsche, L., Williams, J., Zahn, A., Andreae, M., Borrmann, M., Bräuer, T., Dörich, R., Dörnbrack, A., Edtbauer, A., Ernle, L., Fischer, H., Giez, A., Granzin, M., Grewe, V., Hahn, V., Harder, H., Heinritzi, M., Holanda, B., Jöckel, P., Kaiser, K., Krüger, O., Lucke, J., Marsing, A., Martin, A., Matthes, S., Pöhlker, C., Pöschl, U., Reifenbergand, S., Ringsdorf, A., Scheibe, M., Tadic, I., Zauner-Wieczorek, M., Henke, R., and Rapp, M.: Cleaner sky during the Covid-19 confinement, Bulletin of the American Meteorological Society, - submitted, 2021.

Wren, S. N., Liggio, J., Han, Y., Hayden, K., Lu, G., Mihele, C. M., Mittermeier, R. L., Stroud, C., Wentzell, J. J., and Brook, J. R.: Elucidating real-world vehicle emission factors from mobile measurements over a large metropolitan region: A focus on isocyanic acid, hydrogen cyanide, and black carbon, Atmospheric Chemistry and Physics, 18, 16 979-17 001, https://doi.org/10.5194/acp-18-16979-2018, 2018.

Zimmermann, P. H., Brenninkmeijer, C. A. M., Pozzer, A., Jöckel, P., Winterstein, F., Zahn, A., Houweling, S., and Lelieveld, J.: Model simulations of atmospheric methane (1997-2016) and their evaluation using NOAA and AGAGE surface and IAGOS-CARIBIC aircraft observations, Atmos Chem Phys, 20, 5787-5809, https://doi.org/10.5194/acp-20-5787-2020, 2020. 